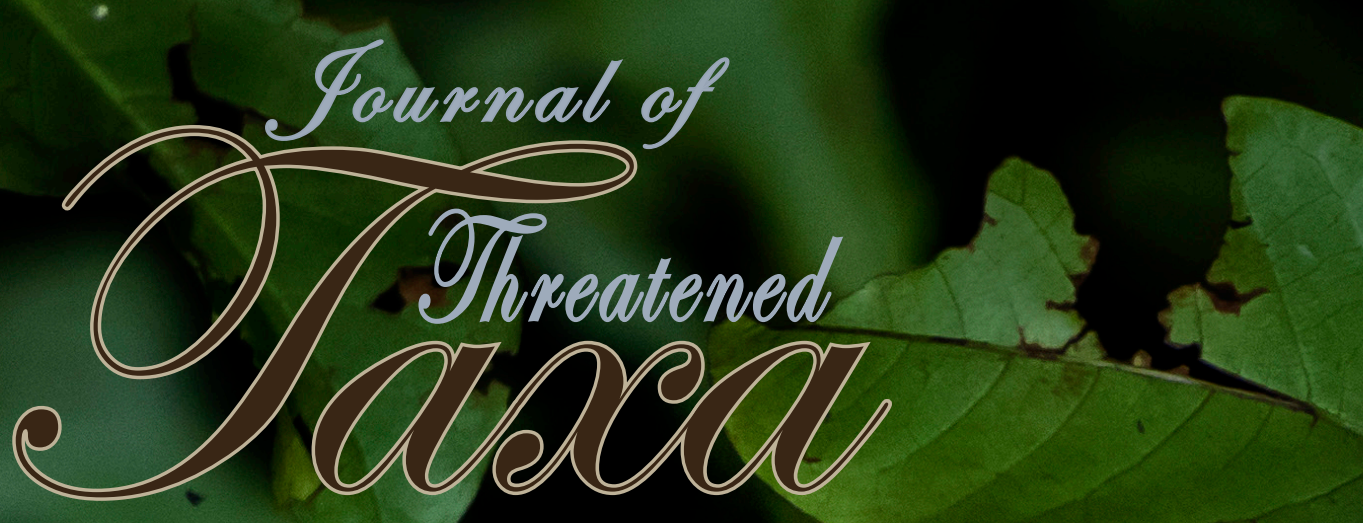

Building exidence for conservation glabally

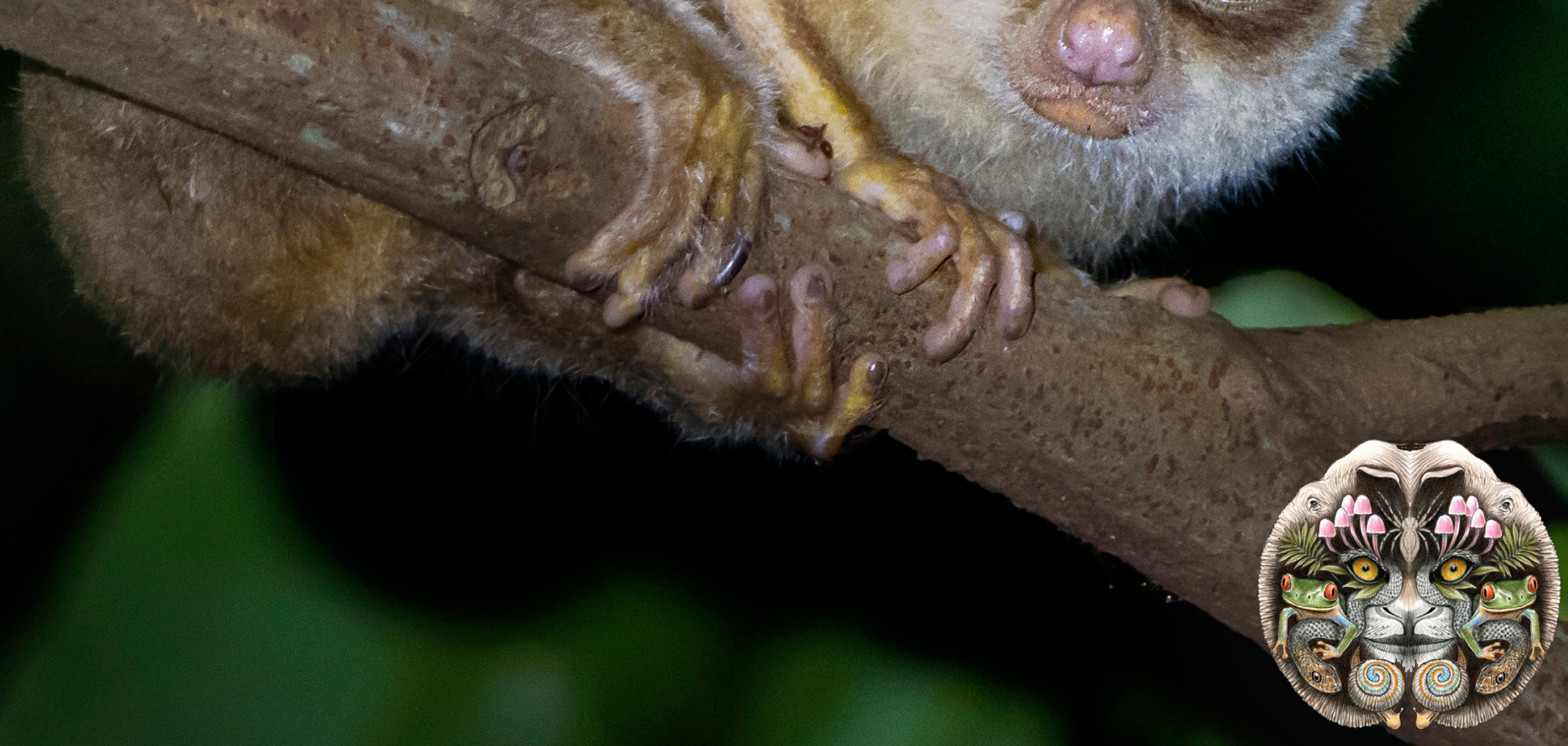

Open Access

$10.11609 /$ jott.2021.13.010.19431-19614 creven.threatenedtaxa.arg

26 September 2021 (Online \& Print) Val. 13 | Na. 11 | Pages: 19431-19674 


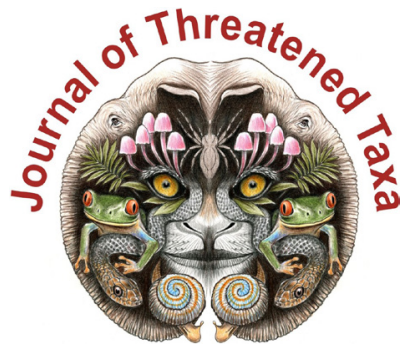

ISSN 0974-7907 (Online); ISSN $0974-7893$ (Print)

Publisher

Host

Wildlife Information Liaison Development Society

www.wild.zooreach.org

Zoo Outreach Organization www.zooreach.org

No. 12, Thiruvannamalai Nagar, Saravanampatti - Kalapatti Road, Saravanampatti, Coimbatore, Tamil Nadu 641035, India

Ph: +91 9385339863 | www.threatenedtaxa.org

Email: sanjay@threatenedtaxa.org

EDITORS

\section{Founder \& Chief Editor}

Dr. Sanjay Molur

Wildlife Information Liaison Development (WILD) Society \& Zoo Outreach Organization (ZOO)

12 Thiruvannamalai Nagar, Saravanampatti, Coimbatore, Tamil Nadu 641035, India

\section{Deputy Chief Edito}

Dr. Neelesh Dahanukar

Noida, Uttar Pradesh, India

\section{Managing Editor}

Mr. B. Ravichandran, WILD/ZOO, Coimbatore, India

\section{Associate Editors}

Dr. Mandar Paingankar, Government Science College Gadchiroli, Maharashtra 442605, India

Dr. Ulrike Streicher, Wildlife Veterinarian, Eugene, Oregon, USA

Ms. Priyanka Iyer, ZOO/WILD, Coimbatore, Tamil Nadu 641035, India

Dr. B. A. Daniel, $200 / \mathrm{WILD}$, Coimbatore, Tamil Nadu 641035, India

\section{Editorial Board}

Dr. Russel Mittermeier

Executive Vice Chair, Conservation International, Arlington, Virginia 22202, USA

\section{Prof. Mewa Singh Ph.D., FASc, FNA, FNASc, FNAPsy}

Ramanna Fellow and Life-Long Distinguished Professor, Biopsychology Laboratory, and Institute of Excellence, University of Mysore, Mysuru, Karnataka 570006, India; Honorary Professor, Jawaharlal Nehru Centre for Advanced Scientific Research, Bangalore; and Adjunct Professor, National Institute of Advanced Studies, Bangalore

\section{Stephen D. Nash}

Scientific Illustrator, Conservation International, Dept. of Anatomical Sciences, Health Sciences Center, T-8, Room 045, Stony Brook University, Stony Brook, NY 11794-8081, USA

\section{Dr. Fred Pluthero}

Toronto, Canada

\section{Dr. Priya Davidar}

Sigur Nature Trust, Chadapatti, Mavinhalla PO, Nilgiris, Tamil Nadu 643223, India

\section{Dr. Martin Fisher}

Senior Associate Professor, Battcock Centre for Experimental Astrophysics, Cavendish

Laboratory, JJ Thomson Avenue, Cambridge CB3 OHE, UK

\section{Dr. John Fellowe}

Honorary Assistant Professor, The Kadoorie Institute, 8/F, T.T. Tsui Building, The University of Hong Kong, Pokfulam Road, Hong Kong

\section{Prof. Dr. Mirco Solé}

Universidade Estadual de Santa Cruz, Departamento de Ciências Biológicas, Vice-coordenado do Programa de Pós-Graduação em Zoologia, Rodovia Ilhéus/Itabuna, Km 16 (45662-000)

Salobrinho, Ilhéus - Bahia - Brasil

\section{Dr. Rajeev Raghavan}

Professor of Taxonomy, Kerala University of Fisheries \& Ocean Studies, Kochi, Kerala, India

\section{English Editors}

Mrs. Mira Bhojwani, Pune, India

Dr. Fred Pluthero, Toronto, Canad

Mr. P. Ilangovan, Chennai, India

Web Maintenance

Mrs. Latha G. Ravikumar, ZOO/WILD, Coimbatore, India

\section{Typesetting}

Mr. Arul Jagadish, ZOO, Coimbatore, India

Mrs. Radhika, ZOO, Coimbatore, India

Mrs. Geetha, ZOO, Coimbatore India

\section{Fundraising/Communications}

Mrs. Payal B. Molur, Coimbatore, India

Subject Editors 2018-2020

Fungi

Dr. B. Shivaraju, Bengaluru, Karnataka, India

Dr. R.K. Verma, Tropical Forest Research Institute, Jabalpur, India

Dr. Vatsavaya S. Raju, Kakatiay University, Warangal, Andhra Pradesh, India

Dr. M. Krishnappa, Jnana Sahyadri, Kuvempu University, Shimoga, Karnataka, India

Dr. K.R. Sridhar, Mangalore University, Mangalagangotri, Mangalore, Karnataka, India

Dr. Gunjan Biswas, Vidyasagar University, Midnapore, West Bengal, India

Plants

Dr. G.P. Sinha, Botanical Survey of India, Allahabad, India

Dr. N.P. Balakrishnan, Ret. Joint Director, BSI, Coimbatore, India

Dr. Shonil Bhagwat, Open University and University of Oxford, UK

Prof. D.J. Bhat, Retd. Professor, Goa University, Goa, India

Dr. Ferdinando Boero, Università del Salento, Lecce, Italy

Dr. Dale R. Calder, Royal Ontaro Museum, Toronto, Ontario, Canada

Dr. Cleofas Cervancia, Univ. of Philippines Los Baños College Laguna, Philippines

Dr. F.B. Vincent Florens, University of Mauritius, Mauritius

Dr. Merlin Franco, Curtin University, Malaysia

Dr. V. Irudayaraj, St. Xavier's College, Palayamkottai, Tamil Nadu, India

Dr. B.S. Kholia, Botanical Survey of India, Gangtok, Sikkim, India

Dr. Pankaj Kumar, Kadoorie Farm and Botanic Garden Corporation, Hong Kong S.A.R., China

Dr. V. Sampath Kumar, Botanical Survey of India, Howrah, West Bengal, India

Dr. A.J. Solomon Raju, Andhra University, Visakhapatnam, India

Dr. Vijayasankar Raman, University of Mississippi, USA

Dr. B. Ravi Prasad Rao, Sri Krishnadevaraya University, Anantpur, India

Dr. K. Ravikumar, FRLHT, Bengaluru, Karnataka, India

Dr. Aparna Watve, Pune, Maharashtra, India

Dr. Qiang Liu, Xishuangbanna Tropical Botanical Garden, Yunnan, China

Dr. Noor Azhar Mohamed Shazili, Universiti Malaysia Terengganu, Kuala Terengganu, Malaysia Dr. M.K. Vasudeva Rao, Shiv Ranjani Housing Society, Pune, Maharashtra, India

Prof. A.J. Solomon Raju, Andhra University, Visakhapatnam, India

Dr. Mandar Datar, Agharkar Research Institute, Pune, Maharashtra, India

Dr. M.K. Janarthanam, Goa University, Goa, India

Dr. K. Karthigeyan, Botanical Survey of India, India

Dr. Errol Vela, University of Montpellier, Montpellier, France

Dr. P. Lakshminarasimhan, Botanical Survey of India, Howrah, India

Dr. Larry R. Noblick, Montgomery Botanical Center, Miami, USA

Dr. K. Haridasan, Pallavur, Palakkad District, Kerala, India

Dr. Analinda Manila-Fajard, University of the Philippines Los Banos, Laguna, Philippines

Dr. P.A. Sinu, Central University of Kerala, Kasaragod, Kerala, India

Dr. Afroz Alam, Banasthali Vidyapith (accredited A grade by NAAC), Rajasthan, India

Dr. K.P. Rajesh, Zamorin's Guruvayurappan College, GA College PO, Kozhikode, Kerala, India

Dr. David E. Boufford, Harvard University Herbaria, Cambridge, MA 02138-2020, USA

Dr. Ritesh Kumar Choudhary, Agharkar Research Institute, Pune, Maharashtra, India

Dr. Navendu Page, Wildlife Institute of India, Chandrabani, Dehradun, Uttarakhand, India

Invertebrates

Dr. R.K. Avasthi, Rohtak University, Haryana, India

Dr. D.B. Bastawade, Maharashtra, India

Dr. Partha Pratim Bhattacharjee, Tripura University, Suryamaninagar, India

Dr. Kailash Chandra, Zoological Survey of India, Jabalpur, Madhya Pradesh, India

Dr. Ansie Dippenaar-Schoeman, University of Pretoria, Queenswood, South Africa

Dr. Rory Dow, National Museum of natural History Naturalis, The Netherlands

Dr. Brian Fisher, California Academy of Sciences, USA

Dr. Richard Gallon, llandudno, North Wales, LL30 1UP

Dr. Hemant V. Ghate, Modern College, Pune, India

Dr. M. Monwar Hossain, Jahangirnagar University, Dhaka, Bangladesh

Mr. Jatishwor Singh Irungbam, Biology Centre CAS, Branišovská, Czech Republic

Dr. lan J. Kitching Natural History Museum, Cromwell Road, UK

Dr. George Mathew, Kerala Forest Research Institute, Peechi, India

Dr. John Noyes, Natural History Museum, London, UK

For Focus, Scope, Aims, and Policies, visit https://threatenedtaxa.org/index.php/JoTT/aims_scope
For Article Submission Guidelines, visit https://threatenedtaxa.org/index.php/JoTT/about/submissions
For Policies against Scientific Misconduct, visit https://threatenedtaxa.org/index.php/JoTT/policies_various 


\title{
A reference of identification keys to plant-parasitic nematodes (Nematoda: Tylenchida\ Tylenchomorpha)
}

\section{Reza Ghaderi ${ }^{1}(\mathbb{D})$, Manouchehr Hosseinvand ${ }^{2}$ (D) \& Ali Eskandari ${ }^{3}(\mathbb{D})$}

\footnotetext{
${ }^{1}$ Department of Plant Protection, School of Agriculture, Shiraz University, 71441-65186, Shiraz, Iran. 2,3 Department of Plant Protection, Faculty of Agriculture, University of Zanjan, 45371-38791, Zanjan, Iran.

${ }^{1}$ rghaderi@shirazu.ac.ir (corresponding author), ${ }^{2}$ m.houseinvand@gmail.com, ${ }^{3}$ eskandari.a@znu.ac.ir
}

\begin{abstract}
The present review has documented a list of keys for identifying plant-parasitic nematodes at different taxonomic levels including superfamily, family, subfamily, genus, and species. It was compiled as a current source of information to assist students and professionals in the discipline of nematology for identification of this important group of soil nematodes.
\end{abstract}

Keywords: Compendium, identification key, Longidoridae, Trichodoridae.

Citation: Ghaderi, R., M. Hosseinvand \& A. Eskandari (2021). A reference of identification keys to plant-parasitic nematodes (Nematoda: Tylenchida Tylenchomorpha). Journal of Threatened Taxa 13(11): 19580-19602. https://doi.org/10.11609/jott.6336.13.11.19580-19602

Copyright: (c) Ghaderi et al. 2021. Creative Commons Attribution 4.0 International License. JoTT allows unrestricted use, reproduction, and distribution of this article in any medium by providing adequate credit to the author(s) and the source of publication.

Funding: None.

Competing interests: The authors declare no competing interests.

Author details: REZA GHADERI is an Assistant Professor of plant nematology at Shiraz University, Iran, working on identification and management of plantparasitic nematodes, particularly Merliniidae, Telotylenchidae and Tylenchulidae. MANOUCHEHR HOSSEINVAND is a PhD student of plant pathology (Nematology) at University of Zanjan, Iran, currently working on identification of the plant-parasitic nematodes of the families Tylenchidae, Merliniidae and Telotylenchidae in southwestern regions of Iran. ALI ESKANDARI is an Associated Professor of Nematology at University of Zanjan, working on identification of plant and soil nematodes particularly Criconematoidea.

Author contributions: All the three authors have contributed throughout the preparation of the manuscript.

Acknowledgements: We wish to gratefully thank the kind help of Dr. Renauld Fortuner (Université de Poitiers, France) and Dr. Erum Yawar lqbal (University of Karachi, Pakistan) for providing of some papers. 


\section{INTRODUCTION}

While working on plant-parasitic nematodes, taxonomists have been documenting several identification keys on this group of nematodes. Although the work by Lewis et al. (1999) can be regarded as a very good documentation including a list of keys and references for identifying species of selected genera of plant-parasitic nematodes, it doesn't cover a large part of current information provided in the literature.

For having a view on classification and general identification of plant-parasitic nematodes, readers may find very helpful the following general references beside of identification keys documented in the present paper: May \& Lyon (1975), Ebsary (1991), Nickle (1991), Siddiqi (2000), Andrássy (2007), Hodda (2011), and ManzanillaLópez \& Marbán-Mendoza (2012). The landmark collection of papers on reappraisal of Tylenchina published in Revue de Nématologie during 1987 and 1988 , is also highly recommended to obtain an excellent insight on the systematics of plant-parasitic nematodes.

In the present paper, nomenclature and systematics follow that of De Ley \& Blaxter $(2002,2004)$ and Kashi \& Karegar (2018) with slight modification. We have tried that the present work to be a comprehensive reference for identification keys to plant-parasitic nematodes; however, some works may be overlooked and thus not included in the list. Keys for identifying plant-parasitic nematodes at different taxonomic levels including superfamily, family, subfamily, genus, and species level are referred. The number of treated taxa is mentioned whenever data (full paper) was available. Taxa are arranged alphabetically, and for each taxon, keys are written based on the order of the year of publication, from the newest to the oldest. Dichotomous keys are simply named 'key', and diagnostic compendiums or tabular keys as 'compendium' throughout the paper.

\section{Keys to plant-parasitic nematodes}

Phylum Nematoda Potts, 1932: Andrássy 2007, Hunt 1995, Hopper \& Cairns 1959

Class Chromadorea Inglis, 1983

Subclass Chromadoria Pearse, 1942

Order Rhabditida Chitwood, 1933

Suborder Tylenchina Thorne, 1949: Mekete et al. 2012 (pictorial key for agriculturally important plantparasitic nematodes), Andrássy 2007 (key for taxa), Eisenback 2002 (pictorial key for 23 genera), Bell 2002 (computerized key for 30 genera), Siddiqi 2000 (key for families and genera), Brzeski 1998 (key for genera),
Bongers 1988 (key for nematodes of the Netherlands), Anderson \& Mulvey 1979 (pictorial key for genera in Canada), Mai \& Lyon 1975 (pictorial key for genera)

Note: This taxon includes plant-parasitic and bacteriovorous nematodes; the above-mentioned keys are only for plant-parasitic taxa.

\section{Infraorder Tylenchomorpha De Ley \& Blaxter, 2002}

Superfamily Aphelenchoidea Fuchs, 1937: Miraeiz 2018 (key for genera) [in Persian], Kanzaki \& GiblinDavis 2012 (key for 2 families), Andrássy 2007 (key for 8 families, as order Aphelenchida), Hunt 1993 (key for 2 families)

Note: Aphelenchid nematodes have been treated under different levels of classificaton in literature: order Aphelenchida, subfamily Aphelenchina, or superfamily Aphelenchoidea. We consider them as a superfamily herein.

Family Aphelenchidae Fuchs, 1937: Kanzaki \& GiblinDavis 2012 (key for 2 subfamilies), Hunt 1993 (key for 2 subfamilies)

Subfamily Aphelenchinae Fuchs, 1937

Aphelenchus Bastian, 1865: Andrássy 2007 (key for 4 European species), Nama \& Soni 1981, Anderson \& Hooper 1980

Subfamily Paraphelenchinae T. Goodey, 1951

Paraphelenchus Micoletzky, 1922: Ryss 2013 (key and compendium for 23 species), Carta et al. 2011 (compendium for 23 species), Andrássy 2007 (key for 7 European species)

Family Aphelenchoididae Skarbilovich, 1947: Kanzaki \& Giblin-Davis 2012 (key for 6 subfamilies and 29 genera), Andrássy 2007 (key for 12 genera), Hunt 1993 (key for 6 subfamilies)

Subfamily Acugutturinae Hunt, 1980: Andrássy 2007 (key for 3 genera), Hunt 1993 (key for 3 genera)

Acugutturus Hunt, 1980

Noctuidonema Remillet \& Silvain, 1988

Vampyronema Hunt, 1993

Subfamily Aphelenchoidinae Skarbilovich, 1947: Hunt 1993 (key for 7 genera)

Aphelenchoides Fischer, 1894: Andrássy 2007 (key for 47 European species), Shahina 1996 (compendium for 141 species), Sanwal 1961 (key for 35 species), 
Thorne \& Malek 1968 (key for 7 species)

Anomyctus Allen, 1940

Basilaphelenchus Pedram, Kanzaki, Giblin-Davis \& Pourjam, 2018

Laimaphelenchus Fuchs, 1937: Asghari et al. 2012 (key for 15 species), Andrássy 2007 (key for 3 European species), Oro et al. (2015) (key to 16 species).

Punchaulus De Ley \& Coomans, 1996

Robustodorus Andrássy, 2007

Ruehmaphelenchus J.B. Goodey, 1963

Schistonchus Cobb, 1927: Davies et al. 2010 (key and compendium for 4 nominal species and 12 morphospecies in Australia)

Sheraphelenchus Nickle, 1970

Subfamily Ektaphelenchinae Paramonov, 1964: Andrássy 2007 (key for 4 genera), Hunt 1993 (key for 4 genera)

Cryptaphelenchus Fuchs, 1937

Devibursaphelenchus Kakuliya, 1967

Ektaphelenchoides Baujard, 1984

Ektaphelenchus Fuchs, 1937

Subfamily Entaphelenchinae Nickle, 1970: Andrássy 2007 (key for 4 genera)

Entaphelenchus Wachek, 1955

Peraphelenchus Wachek, 1955

Praecocilenchus Poinar, 1969

Roveaphelenchus Nickle, 1970

Subfamily Parasitaphelenchinae Rühm, 1956

Parasitaphelenchus Fuchs, 1929

Bursaphelenchus Fuchs, 1937: Andrássy 2007 (key for 33 European species), Ryss et al. 2005 (key and compendium for 75 species), Yin et al. 1988 (key and compendium for 44 species), Tarjan \& Aragon 1982, Maria et al. 2016 (key to 19 species of hofmanni-group).

Subfamily Sinurinae Husain \& Khan, 1967: Andrássy 2007 (key for 3 genera), Hunt 1993 (key for 4 genera)

Aprutides Scognamiglio, Talame' \& S'Jacob, 1970

Papuaphelenchus Andrássy, 1973

Seinura Fuchs, 1931: Andrássy 2007 (key for 15 European species), Shahina \& Hunt 1995 (compendium for 39 species)

Subfamily Tylaphelenchinae Kanzaki, Li, Lan \& Giblin-Davis, 2014

Pseudaphelenchus Kanzaki \& Giblin-Davis, 2009 in Kanzaki et al. (2009)

Tylaphelenchus Rühm, 1956
Superfamily Criconematoidea Taylor, 1936: Cid del Prado Vera \& Talavera 2012 (key for 3 families), Andrássy 2007 (key for families), Siddiqi 1980 (key for families)

Note: Siddiqi (2000) considered this group as suborder Criconematina, and prodided identification keys for all taxa from genus to superfamily level.

Family Criconematidae Taylor, 1936: Cid del Prado Vera \& Talavera 2012 (key for 3 subfamilies and 9 genera), Geraert 2010 (key for 18 genera), Andrássy 2007 (key for 17 genera), Wouts 2006 (key for taxa of New Zealand), Andrássy 1979 (key for taxa), De Grisse 1969 (key and compendium for taxa)

Subfamily Blandicephalanematinae Geraert, 2010

Amphisbaenema Orton Williams, 1982: Geraert 2010 (description of 1 species)

Blandicephalanema Mehta \& Raski, 1971: Geraert 2010 (key for 5 species)

Subfamily Criconematinae Taylor, 1936

Criconema Hofmänner \& Menzel, 1914: Geraert 2010 (key for 99 species), Andrássy 2007 (key for 15 European species), Brzeski 1998 (key for 6 European species), Yeates et al. 1997 (key for 19 species), Golden \& Friedman 1964 (key for 30 species)

Croserinema Khan, Chawla \& Saha, 1976: Geraert 2010 (key for 3 species), Crozzoli \& Lamberti 2002 (key for 5 species from Venezuela)

Crossonema Mehta \& Raski, 1971: Geraert 2010 (key for 35 species), Andrássy 2007 (key for 5 European species)

Lobocriconema De Grisse \& Loof, 1965: Geraert 2010 (key for 19 species)

Neolobocriconema Mehta \& Raski, 1971: Geraert 2010 (key for 11 species), Hashim 1984

Ogma Southern, 1914: Geraert 2010 (key for 77 species), Andrássy 2007 (key for 9 European species), Crozzoli \& Lamberti 2002 (key for 3 species from Venezuela), Brzeski 1998 (key for 8 European species), Van den Berg \& Quinéhérve 1995 (key and compendium for 10 species with predominantly 12 longitudinal rows of cuticular scales), Minagawa 1993 (compendium for 13 species)

Orphreyus Siddiqi, 2000: Geraert 2010 (key for 3 species)

Pateracephalanema Mehta \& Raski, 1971: Geraert 2010 (key for 3 species)

Subfamily Discocriconemellinae Geraert, 2010

Discocriconemella De Grisse \& Loof, 1965: Geraert 
2010 (key for 29 species)

Xenocriconemella De Grisse \& Loof, 1965: Geraert 2010 (key for 2 species), Andrássy 2007 (key for 2 European species)

Subfamily Hemicriconemoidinae Andrássy, 1979

Hemicriconemoides Chitwood \& Birchfield, 1957: Geraert 2010 (key for 51 species), Esser \& Vovlas 1990 (compendium for species), Germani \& Luc 1970, Dasgupta et al. 1969 (key for 16 species)

Subfamily Macroposthoniinae Skarbilovich, 1959

Bakernema Wu, 1964: Geraert 2010 (key for 2 species), Ebsary 1982

Criconemoides Taylor, 1936: Geraert 2010 (key for 45 species), Andrássy 2007 (key for 10 European species), Brzeski et al. 2002 (compendium for 34 species), Brzeski 1998 (key for 4 European species), Ebsary 1979, Mehta \& Raski 1971, Tarjan 1966 (key and compendium for 89 species including Mesocriconema species), Raski \& Golden 1966 (key for 85 species including Mesocriconema species), De Grisse \& Loof 1965, Raski 1952 (key for 22 species)

Mesocriconema Andrássy, 1965: Geraert 2010 (key for 90 species), Andrássy 2007 (key for 25 European species), Brzeski et al. 2002 (compendium for 90 species), Crozzoli \& Lamberti 2001 (key for 11 species from Venezuela), Brzeski 1998 (key for 17 European species), Loof \& De Grisse 1989

Neobakernema Ebsary, 1981: Geraert 2010 (key for 7 species)

Nothocriconemoides Maas, Loof \& De Grisse, 1971: Geraert 2010 (key for 2 species)

Family Hemicycliophoridae Skarbilovich, 1959: Chitambar \& Subbotin 2014 (key for 2 subfamilies), Cid del Prado Vera \& Talavera 2012 (key for 2 subfamilies and 4 genera), Andrássy 2007 (key for 4 genera), Siddiqi 1980 (key for taxa)

Subfamily Caloosiinae Siddiqi, 1980: Chitambar \& Subbotin 2014 (key for 2 genera)

Caloosia Siddiqi \& Goodey, 1964: Chitambar \& Subbotin 2014 (key and compendium for 8 species)

Hemicaloosia Ray \& Das, 1978: Chitambar \& Subbotin 2014 (key and compendium for 9 species); Zeng et al. 2012 (key and compendium for 7 species)

Subfamily Hemicycliophorinae Skarbilovich, 1959: Siddiqi 1980 (key for 4 genera)

Hemicycliophora de Man, 1921: Chitambar \&
Subbotin 2014 (key and compendium for 132 species), Andrássy 2007 (key for 16 European species), Brzeski 1998 (key for 12 European species), Van den Berg 1987, Brzeski \& Ivanova 1978, Eroshenko 1976, Loof 1976, Brzeski 1974, Loof 1968, Schoemaker 1967 (key for 44 species)

Family Tylenchulidae Skarbilovich, 1947: Ghaderi et al. 2016 (key for 4 subfamilies and 8 genera), Cid del Prado Vera \& Talavera 2012 (key for 4 subfamilies and 7 genera), Raski 1991 (key for 3 subfamilies)

\section{Subfamily Meloidoderitinae Kirjanova \& Poghossian, 1973 \\ Meloidoderita Poghossian, 1966: Ghaderi et al. 2016 (key for 4 species), Raski 1991 (key for 3 species)}

Subfamily Paratylenchinae Thorne, 1949: Ghaderi et al. 2016 (key for 3 genera), Andrássy 2007 (key for 5 genera), Esser 1992 (compendium for 148 species), Raski 1991 (key for 3 genera)

Cacopaurus Thorne, 1943: Ghaderi et al. 2016 (description of 1 species)

Paratylenchus Micoletzky, 1922: Ghaderi et al. 2016 (key for 130 species), Ghaderi et al. 2014 (key and compendium for 117 species), Andrássy 2007 (key for 30 European species under Paratylenchus or Gracilacus), Brzeski 1998 (key for 16 European species, compendium for 108 species), Raski 1991 (key for 97 species under Paratylenchus and Gracilacus), Pinochet \& Raski 1977 (amended key of Raski 1975), Raski 1976 (key for 29 species with stylet longer than $40 \mu \mathrm{m}$ ), Raski 1975 (key for 47 species with stylet under $40 \mu \mathrm{m}$ ), Soloveva 1975 (key for 44 species), Wu 1975 (key for 10 Canadian species), Geraert 1965 (key for 39 species)

Tylenchocriconema Raski \& Siddiqui, 1975: Ghaderi et al. 2016 (description of 1 species)

Subfamily Sphaeronematinae Raski \& Sher, 1952: Andrássy 2007 (key for 4 genera including Meloidoderita)

Sphaeronema Raski \& sher, 1952: Ghaderi et al. 2016 (key for 9 species), Raski 1991 (key for 8 species)

Subfamily Tylenchulinae Skarbilovich, 1947: Ghaderi et al. 2016 (key for 3 genera), Andrássy 2007 (key for 2 genera), Raski 1991 (key for 5 genera including Meloidoderita and Sphaeronema)

Boomerangia Siddiqi, 1994: Ghaderi et al. 2016 (key for 2 species)

Trophotylenchulus Raski, 1957: Ghaderi et al. 2016 (key for 14 species), Raski 1991 (key for 10 species under 
Trophotylenchulus and Trophonema)

Tylenchulus Cobb, 1913: Ghaderi et al. 2016 (key for 5 species), Tanha Maafi et al. 2012 (key for 5 species), Raski 1991 (key for 4 species), Inserra et al. 1988 (key for 4 species)

\section{Superfamily Tylenchoidea Örley, 1880}

Family Dolichodoridae Whitehead, 1959: Hunt et al. 2013 (key for 6 subfamilies), Geraert 2011 (key for 7 subfamilies), Smart \& Nguyen 1991 (key for 3 genera)

Subfamily Belonolaiminae Whitehead, 1960: Hunt et al. 2013 (key for 4 genera), Geraert 2011 (key for 4 genera), Andrássy 2007 (key for 4 genera), Smart \& Nguyen 1991 (key for 5 genera)

Belonolaimus Steiner, 1949: Geraert 2011 (key for 5 species), Smart \& Nguyen 1991 (key for 9 species), Rau 1963 (key for 5 species), Cid Del Prado \& Subbotin 2012 (key to 6 species)

Carphodorus Colbran, 1965: Geraert 2011 (description of 1 species)

Ibipora Monteiro \& Lordello, 1977: Geraert 2011 (key for 5 species)

Morulaimus Sauer, 1966: Geraert 2011 (key for 8 species), Smart \& Nguyen 1991 (key for 6 species)

Subfamily Brachydorinae Siddiqi, 2000

Brachydorus de Guiran \& Germani, 1968: Geraert 2011 (key for 3 species)

Subfamily Dolichodorinae Chitwood in Chitwood \& Chitwood, 1950: Hunt et al. 2013 (key for 2 genera), Geraert 2011 (key for 2 genera), Andrássy 2007 (key for 3 genera), Smart \& Nguyen 1991 (key for 3 genera), Lewis \& Golden 1981 (key for 3 genera)

Dolichodorus Cobb, 1914: Geraert 2011 (key for 17 species), Guirado et al. 2007 (key and compendium for 17 species), Smart \& Nguyen 1991 (key for 15 species), Lewis \& Golden 1981 (key for 9 species), Smart \& Khuong 1985 (key for 13 species), Grove et al. 1985, Loof \& Sharma 1975, Esser 1989

Neodolichodorus Andrássy, 1976: Geraert 2011 (key for 12 species), Smart \& Nguyen 1991 (key for 7 species)

Subfamily Macrotrophurinae Fotedar \& Handoo, 1978

Macrotrophurus Loof, 1958: Geraert 2011 (description of 1 species)

Subfamily Meiodorinae Siddiqi, 1976

Meiodorus Siddiqi, 1976: Geraert 2011 (key for 3 species).

Family Merliniidae Siddiqi, 1971: Ghaderi et al. 2017 (key for8 genera), Hunt et al. 2013 (key for 5 genera), Sturhan 2012 (compendium for 7 genera), Geraert 2011 (key for 3 genera)

Subfamily Merliniinae Siddiqi, 1971

Amplimerlinius Siddiqi, 1976: Ghaderi \& Karegar 2014, Geraert 2011 (key for 22 species), Andrássy 2007 (key for 11 European species), Brzeski 1998 (key for 5 European species), Shaw \& Khan 1992 (key for 7 species), Bello et al. 1987 (compendium for 14 species), Brzeski 1985, Hooper 1978 (key and compendium for 9 species)

Geocenamus Thorne \& Malek, 1968: Geraert 2011 (key for 69 species of Geocenamus, Merlinius and Paramerlinius), Chitambar \& Ferris 2005 (key and compendium for 12 species), Smart \& Nguyen 1991 (key for 7 species), Hooper 1978 (key and compendium for 3 species), Tarjan 1973 (key and compendium for 3 species)

Macrotylenchus Sturhan, 2012: Ghaderi et al. 2017 (key for 3 species)

Merlinius Siddiqi, 1970: Ghaderi et al. 2017 (key for 31 species), Andrássy 2007 (key for 9 European species), Handoo et al. 2007 (key and compendium for 32 species), Brzeski 1998 (key for 19 European species, compendium for 77 species including Geocenamus and Scutylenchus species), Brzeski 1992 (supplement for the key in Brzeski 1991), Brzeski 1991 (key for 67 species including Geocenamus and Scutylenchus species), Hooper 1978 (key and compendium for 46 species including Scutylenchus species), Tarjan 1973 (key and compendium for 38 species including Scutylenchus species)

Nagelus Thorne \& Malek, 1968: Ghaderi et al. 2017 (key for 9 species), Geraert 2011 (key for 27 species), Andrássy 2007 (key for 8 European species), Brzeski 1998 (key for 2 European species), Powers et al. 1983 (compendium for 6 species)

Paramerlinius Sturhan, 2012: Ghaderi et al. 2017 (key for 11 species)

Scutylenchus Jairajpuri, 1971: Ghaderi \& Karegar 2016 (key and compendium for 32 species including Geocenamus species), Xu et al. 2012 (key for 24 species), Andrássy 2007 (key for 9 European species), Skwiercz 1984 (key for 15 species)

Telomerlinius Siddiqi \& Sturhan, 2014: Siddiqi \& Sturhan 2014 (key for 2 species) 
Subfamily Pratylenchoidinae Sturhan, 2012

Pratylenchoides Winslow, 1958: Ghaderi \& Karegar 2014 (key and compendium for 26 species), Geraert 2013 (key for 29 species), Ryss 2007 (key and compendium for 26 species) [in Russian], Andrássy 2007 (key for 17 European species), Brzeski 1998 (key for 7 European species), Talavera \& Tobar 1996 (key for 23 species), Loof 1991 (key for 19 species), Baldwin et al. 1983 (key for 14 species), Ryss 1980.

Family Telotylenchidae Siddiqi, 1960: Hunt et al. 2013 (key for 9 genera), Geraert 2011 (key for 9 genera), Andrássy 2007 (key for 18 genera including those in Merliniidae), Jairajpuri \& Hunt 1984 (key for 11 genera), Hooper 1978 (key for 3 subfamilies and 13 genera including those in Merliniidae), Tarjan 1973 (key for 8 genera including Merliniidae genera).

Subfamily Telotylenchinae Siddiqi, 1960: Jairajpuri \& Hunt 1984 (key for 11 genera)

Bitylenchus Filipjev, 1934: Hosseinvand et al. 2020 (key for 140 species including Tylenchorhynchus and Sauertylenchus), Andrássy 2007 (key for 12 European species), Jairajpuri 1982.

Histotylenchus Siddiqi, 1971: Geraert 2011 (key for 7 species)

Macrotrophurus Loof, 1958: Geraert 2011 (description of 1 species)

Neodolichorhynchus Jairajpuri \& Hunt, 1984: Geraert 2011 (key for 20 species), Andrássy 2007 (key for 6 European species), Jairajpuri \& Hunt 1994 (key for 11 species under Neodlichorhynchus, Dolichorhynchus Mulk \& Jairajpuri, 1974 and Tessellus Jairajpuri \& Hunt, 1984), Erum et al. 2011 (key to 9 species).

Paratrophurus Arias, 1970: Geraert 2011 (key for 18 species), Andrássy 2007 (key for 3 European species), Brzeski 1998 (key for 2 European species), Castillo et al. 1989 (key for 12 species), Hooper 1978 (key and compendium for 5 species)

Quinisulcius Siddiqi, 1971: Geraert 2011 (key for 17 species), Andrássy 2007 (key for 5 European species), Maqbool 1982 (key for 10 species), Hooper 1978 (key and compendium for 9 species), Tarjan 1973 (key and compendium for 7 species).

Sauertylenchus Sher, 1974: Hosseinvand et al. 2020 (key for 140 species including Bitylenchus and Tylenchorhynchus), Geraert 2011 (description of 1 species).

Telotylenchus Siddiqi, 1960: Geraert 2011 (key for 19 species)

Trichotylenchus Whitehead, 1960: Geraert 2011 (key for 31 species)

Trophurus Loof, 1956: Geraert 2011 (key for 14 species), Brzeski 1998 (key for 2 European species), Kleynhans \& Cadet 1994 (key and compendium for 14 species), Hooper 1978 (key and compendium for 7 species).

Tylenchorhynchus Cobb, 1913: Hosseinvand et al. 2020 (key for 140 species including Bitylenchus and Sauertylenchus), Ganguly et al. 2013 (compendium to 158 species), Geraert 2011 (key for 133 species including Bitylenchus species), Andrássy 2007 (key for 16 European species), Handoo 2000 (key and compendium for 111 species), Brzeski \& Dolinski 1998 (compendium for 177 species of Tylenchorhynchus sensu lato), Brzeski 1998 (key for 9 European species and compendium for 160 species of Tylenchorhynchus sensu lato), Hooper 1978 (key and compendium for 55 species), Tarjan 1973 (key and compendium for 46 species), Tarjan 1964 (key and diagnostic compendium for 88 species of Tylenchorhynchus sensu lato), Thorne \& Malek 1968 (key for 9 species), Allen 1955 (key for 34 species of Tylenchorhynchus sensu lato).

Family Hoplolaimidae Filipjev, 1934: Andrássy 2007 (key for 13 genera excluding cyst and cystoid nematodes), Krall 1990 (key for 3 subfamilies)

Subfamily Acontylinae Fotedar \& Handoo, 1978

Acontylus Meagher, 1968

Subfamily Aphasmatylenchinae Sher, 1965

Aphasmatylenchus Sher, 1965

Subfamily Ataloderinae Wouts, 1973: Ghaderi 2019 (key and compendium for 9 genera)

Atalodera Wouts \& Sher, 1971: Ghaderi 2019 (key for 9 species)

Bellodera Wouts, 1985: Ghaderi 2019 (description of 1 species)

Camelodera Krall, Shagalina \& Ivanova, 1988: Ghaderi 2019 (description of 1 species)

Cryphodera Colbran, 1966: Ghaderi 2019 (key for 7 species), Zhou et al. 2014 (key for 7 species), Karssen \& Van Aelst 1999 (key for 6 species)

Ekphymatodera Bernard \& Mundo-Ocampo, 1989: Ghaderi 2019 (description of 1 species)

Hylonema Luc, Taylor \& Cadet, 1978: Ghaderi 2019 (description of 1 species)

Rhizonemella (Cid del Prado, Lownsbery \& Maggenti, 1983) Andrássy, 2007: Ghaderi 2019 (description of 1 species)

Sarisodera Wouts \& Sher, 1971: Ghaderi 2019 
(description of 1 species)

Subfamily Heteroderinae Filipjev \& Schuurmans Stekhoven, 1941: Subbotin \& Franco 2012 (key for 8 genera), Subbotin et al. 2010 (key for 7 genera), Andrássy 2007 (key for 18 genera including cystoid nematodes), Handoo 2002, Wouts \& Baldwin 1998 (key for 6 genera), Baldwin \& Mundo-Ocampo 1991 (key for 16 genera in Heteroderinae, Ataloderinae and Meloidoderinae), Baldwin \& Schouest 1990, Lamberti \& Taylor 1986 (key for 6 genera and 59 species), Golden 1986 (key for 6 genera and 59 species), Wouts 1985, Mulvey \& Golden 1983 (key and compendium for 6 genera and 34 species).

Betulodera Sturhan, 2002: Subbotin et al. 2010 (description of 1 species)

Cactodera Krall \& Krall, 1978: Cid del Prado Vera \& Subbotin 2014 (key for 14 species), Subbotin et al. 2010 (key and compendium for 13 species), Cid del Prado Vera \& Miranda 2008 (key for 14 species), Graney \& Bird 1990 (key and compendium for 7 species)

Dolichodera Mulvey \& Ebsary, 1980: Subbotin et al. 2010 (description of 1 species)

Globodera Skarbilovich, 1959: Subbotin et al. 2010 (key and compendium for 10 species), Brzeski 1998 (key for 4 European species), Wouts \& Baldwin 1998 (key for 8 species), Baldwin \& Mundo-Ocampo 1991 (key for 6 species of particular economic importance), Wouts 1984 (key for 8 species)

Heterodera Schmidt, 1871: Subbotin et al. 2010 (key and compendium for 80 species), Tanha Maafi et al. 2007 (compendium for 5 species in $H$. avenae group from Iran), Handoo 2002 (key and compendium for 12 species in H. avenae group), Brzeski 1998 (key for 18 European species), Wouts \& Baldwin 1998 (key for 64 species), Wouts et al. 1995 (key for 9 species in H. avenae group), Baldwin \& Mundo-Ocampo 1991 (key for 8 species of particular economic importance), Mulvey 1972 (key for 39 species, including 132 photomicrographs).

Paradolichodera Sturhan, Wouts \& Subbotin, 2007: Subbotin et al. 2010 (description of 1 species)

Punctodera Mulvey \& Stone, 1976: Subbotin et al. 2010 (key and compendium for 4 species)

Vittatidera Bernard, Handoo, Powers, Donald \& Heinz, 2010

Subfamily Hoplolaiminae Filipjev, 1934: Krall 1990 (key for 4 genera)

Aorolaimus Sher, 1963: Baujard et al. 1994 (key for 33 species), Krall 1990 (key for 7 species), Sher 1963 (key for 3 species)

Hoplolaimus Daday, 1905: Ghaderi et al. (Key for 36 species), Handoo \& Golden 1992 (key and compendium for 29 species), Krall 1990 (key for 18 species), Anderson 1983 (key for 13 species having 6 pharyngeal gland nuclei), Jairajpuri \& Baqri 1973 (key for 15 species), Sher 1963 (key for 8 species).

Peltamigratus Sher, 1964: Krall 1990 (key for 11 species), Rashid et al. 1987 (compendium for 25 species), Bittencourt \& Huang 1986 (key for 24 species), Mulk \& Siddiqi 1982.

Scutellonema Andrássy, 1958: Krall 1990 (key for 31 species), Germani et al. 1985 (key for 22 species), Van den Berg \& Heyns 1973, Sher 1965, Sher 1963 (key for 11 species), Kolombia et al. 2017 (key to 50 species).

Subfamily Meloidoderinae Golden, 1971

Meloidodera Chitwood, Hannon \& Esser, 1956: Ghaderi 2019 (key for 10 species), Cid del Prado Vera 1991 (key for 7 species)

\section{Subfamily Rotylenchoidinae Whitehead, 1958 \\ Antarctylus Sher, 1973}

Helicotylenchus Steiner, 1945: Nguyen \& Anh 2019 (key for 37 species from Vietnam), Uzma et al. 2015 (illustrated compendium for 230 species, key for 32 species in Pakistan), Ganguly et al. 2013 (compendium for 203 species), Andrássy 2007 (key for 35 European species), Brzeski 1998 (key for 10 European species), Firoza \& Maqbool 1994 (illustrated compendium for 190 species), Wouts \& Yeates 1994 (key for 13 New Zealandian species), Diederich et al. 1991 (computerized key), Krall 1990 (key for 100 species), Fortuner 1989 (computerized key), Boag \& Jairajpuri 1985 (compendium for 154 species), Fotedar \& Kaul 1985 (key for 125 species), Fortuner \& Wong 1984 (computerized key), Anderson \& Eveleigh 1982 (key for Canadian species), Anderson 1979 (key for 50 species not included in the previous keys), Siddiqi 1972 (key for 75 species), Thorne \& Malek 1968 (key for 10 species), Sher 1966 (key for 41 species).

Pararotylenchus Baldwin \& Bell, 1981: Baldwin \& Bell 1981 (key for 8 species)

Rotylenchus Filipjev, 1936: Andrássy 2007 (key for 35 European species), Castillo \& Vovlas 2005 (key and compendium for 92 species), Brzeski 1998 (key for 11 European species, compendium for 96 species), Geraert \& Barooti 1996 (key for 74 species), Castillo et al. 1994, Krall 1990 (key for 32 species), Boag \& Hooper 1981, Sher 1965 (key for 14 species), Scotto et al. 2000 (compendium for 103 species).

Subfamily Rotylenchulinae Husain \& Khan, 1967: Andrássy 2007 (key for 3 genera), Jatala 1991 (key for 
3 genera)

Rotylenchulus Linford \& Oliveira, 1940: Andrássy 2007 (key for 5 European species), Robinson et al. 1997 (key for 10 species), Jatala 1991 (key for 10 species), Germani 1978 (key for 8 species).

Senegalonema Germani, Luc \& Baldwin, 1984

Subfamily Verutinae Esser, 1981

Verutus Esser, 1981

Bilobodera Sharma \& Siddiqi, 1992

Family Meloidogynidae Skarbilovich, 1959: Hunt \& Handoo 2013 (key for 3 genera), Andrássy 2007 (key for 4 genera)

Subfamily Meloidogyninae Skarbilovich, 1959

Meloidogyne Goeldi, 1892: Ghaderi \& Karssen 2020 (compendium for 105 species based on J2 and male), Zhao et al. 2017 (key to species in New Zealand), Hunt \& Handoo 2009 (description of 12 important species), Karssen 2002 (key for 14 European species), Karssen \& Van Hoenselaar 1998 (key for 14 European species), Brzeski 1998 (key for 8 European species), Eisenback \& Triantaphyllou 1991 (key and compendium for 9 agriculturally most important species based on different life stages), Jepson 1987 (an illustrated monograph including key and compendium for 54 species), Jepson 1983 (key for 24 species), Ebsary \& Eveleigh 1983 (key for 5 Canadian species), Hewlett \& Tarjan 1983 (key and compendium for 53 species), Eisenback et al. 1981 (key and compendium for 4 main species), Taylor \& Sasser 1978 (description of 24 species).

Family Pratylenchidae Thorne, 1949: Geraert 2013 (key for 5 subfamilies and 14 genera), Castillo et al. 2012 (key and compendium for 11 genera), Andrássy 2007 (key for 10 genera), Brzeski 1998 (key for 5 genera), Loof 1991 (key for 9 genera)

Subfamily Apratylenchinae Trinh, Waeyenberge, Nguyen, Baldwin, Karssen \& Moens, 2009

Apratylenchus Trinh, Waeyenberge, Nguyen, Baldwin, Karssen \& Moens, 2009: Geraert 2013 (description of 2 species)

Subfamily Hirschmanniellinae Fotedar \& Handoo, 1978

Hirschmanniella Luc \& Goodey, 1964: Geraert 2013 (key for 37 species), Andrássy 2007 (key for 6 European species), Brzeski 1998 (key for 2 European species), Loof 1991 (key for 25 species), Ebsary \& Anderson 1982,
Sivakumar \& Khan 1982, Khun et al. 2015 (compendium for 29 species).

Subfamily Nacobbinae Chitwood in Chitwood \& Chitwood, 1950

Nacobbus Thorne \& Allen, 1944: Geraert 2013 (description of 2 species), Jatala 1991 (key for 2 species), Sher 1970 (revision of 4 species)

Subfamily Nacobboderinae Golden \& Jansen, 1974: Geraert 2013 (key for 2 genera and 6 species)

Bursadera Ivanova \& Krall, 1985: Geraert 2013 (description of 1 species)

Meloinema Choi \& Geraert, 1974: Geraert 2013 (key for 5 species)

Subfamily Pratylenchinae Thorne, 1949: Geraert 2013 (key for 2 genera)

Pratylenchus Filipjev, 1936: Geraert 2013 (key for 98 species), Castillo \& Vovlas 2007 (key and compendium for 68 species), Andrássy 2007 (key for 26 European species), Brzeski 1998 (key for 16 European species), Loof 1991 (key for 46 species), Handoo \& Golden 1989 (key and compendium for 63 species), Café Filho \& Huang 1989 (key for 54 species), Frederick \& Tarjan 1989 (key and compendium for 89 species), Ryss 1988, Loof 1978, Thorne \& Malek 1968 (key for 4 species), Ryss 2002 (key to 66 species)

Zygotylenchus Siddiqi, 1963: Geraert 2013 (key for 3 species)

Subfamily Radopholinae Allen \& Sher, 1967: Geraert 2013 (key for 7 genera)

Achlysiella Hunt, Bridge \& Machon, 1989: Geraert 2013 (key for 6 species)

Apratylenchoides Sher, 1973: Geraert 2013 (key for 3 species)

Hoplotylus S'Jacob, 1959: Geraert 2013 (key for 4 species), Bernard \& Niblack 1982 (key for 3 species)

Radopholoides de Guiran, 1967: Geraert 2013 (key for 5 species)

Radopholus Thorne, 1949: Geraert 2013 (key for 23 species), Ryss 1997 (computerized key), Loof 1991 (key for the 2 most economic importance species), Sher 1968 (key for 11 species), Ryss 2003 (key and compendium to 29 species)

Zygradus Siddiqi, 1991: Geraert 2013 (description of 2 species)

Family Tylenchidae Örley, 1880: Hunt et al. 2013 (key for 40 genera), Geraert 2008 (key for 42 genera), 
Andrássy 2007 (key for 29 genera), Brzeski 1998 (key for 20 genera), Geraert 1991 (key for 33 genera), Sumenkova 1984 (key for genera) [in Russian], Andrássy 1979a (key for genera and species).

Subfamily Atylenchinae Skarbilovich, 1959: Geraet 2008 (key for 5 genera), Andrássy 2007 (key for 2 genera)

Aglenchus Andrássy, 1954: Husseinvand et al. 2016 (key for 9 species), Geraet 2008 (key for 8 species), Geraert 1991 (key for 3 species), Andrássy 1980

Atylenchus Cobb, 1913: Geraet 2008 (description of 1 species)

Coslenchus Siddiqi, 1978: Geraet 2008 (key for 37 species), Andrássy 2007 (key for 22 European species), Brzeski 1998 (key for 17 European species, compendium for 25 species), Geraert \& Raski 1988 (key for 30 species), Brzeski 1987 (key for 23 species), Mizukubo \& Minagawa 1985 (key for 31 species), Andrássy 1982, Siddiqi 1980 (key for 9 species).

Pleurotylenchus Szczygiel, 1969: Geraet 2008 (description of 2 species)

Subfamily Boleodorinae Khan, 1964: Geraet 2008 (key for 8 genera), Brzeski \& Sauer 1982 (key for 5 genera)

Basiria Siddiqi, 1959: Geraet 2008 (key for 42 species), Andrássy 2007 (key for 12 European species), Karegar \& Geraert 1998 (key for 35 species), Brzeski 1998 (key for 7 European species).

Boleodorus Thorne, 1941: Geraet 2008 (key for 30 species), Andrássy 2007 (key for 4 European species), Brzeski 1998 (key for 3 European species), Geraert 1971 (key for 13 species), Thorne \& Malek 1968 (key for 3 species), Khan 1963.

Discopersicus Yaghoubi, Pourjam, Álvarez-Ortega, Liébanas, Atighi \& Pedram, 2016

Neopsilenchus Thorne and Malek, 1968: Geraet 2008 (key for 9 species), Karegar \& Geraert 1997 (key for 6 species), Shahina \& Maqbool 1990 (key for 11 species), Sultan et al. 1987, Khan \& Khan 1975.

Neothada Khan, 1973: Geraet 2008 (key for 6 species), Andrássy 2007 (key for 2 European species), Brzeski 1998 (key for 2 European species), Heyns \& Van den Berg 1996 (key for 6 species).

Ridgellus Siddiqi, 2000: Geraet 2008 (description of 1 species)

Thada Thorne, 1941: Geraet 2008 (description of 1 species)

Subfamily Ecphyadophorinae Skarbilovich, 1959: Geraet 2008 (key for 9 genera), Andrássy 2007 (key for 9 genera)
Chilenchus Siddiqi, 2000: Geraet 2008 (description of 1 species)

Ecphyadophora de Man, 1921: Geraet 2008 (key for 8 species), Geraert 1991 (key for 6 species), Raski et al. 1982

Ecphyadophoroides Corbett, 1964: Geraet 2008 (key for 2 species), Geraert 1991 (key for 8 species)

Epicharinema Raski, Maggenti, Koshy \& Sosamma, 1982: Geraet 2008 (description of 1 species)

Labrys Qing \& Bert, 2018

Lelenchus Andrássy, 1954: Geraet 2008 (key for 3 species)

Mitranema Siddiqi, 1986: Geraet 2008 (key for 2 species)

Sigmolenchus Gharahkhani, Pourjam, Abolafia, Castillo \& Pedram, 2020

Tenunemellus Siddiqi, 1986: Geraet 2008 (key for 6 species)

Tremonema Siddiqi, 1994: Geraet 2008 (description of 1 species)

Ultratenella Siddiqi, 1994: Geraet 2008 (description of 1 species)

Subfamily Psilenchinae Paramonov, 1967: Andrássy 2007 (key for 3 genera)

Antarctenchus Spaull, 1972: Geraet 2008 (description of 1 species)

Atetylenchus Khan, 1973: Hosseinvand et al. 2020 (key for 7 species), Geraet 2008 (key for 3 species)

Psilenchus de Man, 1921: Geraet 2008 (key for 21 species), Andrássy 2007 (key for 5 European species), Brzeski 1998 (key for 4 European species), Doucet 1996, Brzeski 1989 (compendium for species), Kheiri 1970 (key for 11 species), Thorne \& Malek 1968 (key for 4 species).

Subfamily Tylenchinae Örley, 1880: Geraet 2008 (key for 14 genera)

Allotylenchus Andrássy, 1984: Geraet 2008 (description of 1 species)

Cervoannulatus Bajaj, 1998: Geraet 2008 (description of 1 species)

Cucullitylenchus Huang \& Raski, 1986: Geraet 2008 (description of 1 species)

Discotylenchus Siddiqi, 1980: Geraet 2008 (key for 6 species)

Filenchus Andrássy, 1954: Geraet 2008 (key for 95 species including Ottolenchus species), Andrássy 2007 (key for 27 European species), Brzeski 1998 (key for 19 European species, compendium for 79 species), Raski \& Geraert 1986 (key for 60 species).

Fraglenchus Siddiqi, 2000: Geraet 2008 (description 
of 1 species)

Gracilancea Siddiqi, 1976: Geraet 2008 (description of 1 species)

Irantylenchus Kheiri, 1972: Geraet 2008 (description of 1 species)

Malenchus Andrássy, 1968: Geraet 2008 (key for 22 species), Andrássy 2007 (key for 16 European species), Brzeski 1998 (key for 11 European species, compendium for 33 species), Geraert \& Raski 1986 (key for 24 species)

Miculenchus Andrássy, 1959: Geraet 2008 (key for 4 species), Geraert 1991 (key for 3 species)

Ottolenchus Husain \& Khan, 1967: Geraet 2008 (key for species along together with Filenchus species), Brzeski 1982 (key for 4 species)

Polenchus Andrássy, 1980: Geraet 2008 (key for 3 species)

Sakia Khan, 1964: Geraet 2008 (key for 7 species)

Silenchus Andrássy, 2001: Geraet 2008 (description of 1 species)

Tanzanius Siddiqi, 1991: Geraet 2008 (description of 1 species)

Tylenchus Bastian, 1865: Geraet 2008 (key for 28 species), Andrássy 2007 (key for 8 European species), Brzeski 1998 (key for 4 European species), Bello 1973 (key for 30 species including Filenchus species), Thorne \& Malek 1968 (key for 10 species), Andrássy 1954.

Subfamily Tylodorinae Paramonov, 1967: Geraet 2008 (key for 5 genera)

Arboritynchus Reay, 1991: Geraet 2008 (description of 1 species)

Campbellenchus Wouts, 1977: Geraet 2008 (key for 2 species)

Cephalenchus Goodey, 1962: Geraet 2008 (key for 20 species), Andrássy 2007 (key for 4 European species), Brzeski 1998 (key for 3 European species), Raski \& Geraert 1986 (key for 11 species), Mizukubo \& Minagawa 1985 (key for 16 species), Sultan \& Jairajpuri 1981.

Eutylenchus Cobb, 1913: Geraet 2008 (key for 6 species), Brzeski 1996 (key for 5 species)

Tylodorus Meagher, 1964: Geraet 2008 (key for 2 species)

Superfamily Sphaerularioidea Lubbock, 1861: Andrássy 2007 (key for families)

Family Anguinidae Nicoll, 1935: Subbotin \& Riley 2012 (compendium for 15 genera), Krall 1991 (key for 3 subfamilies), Andrássy 2007 (key for 14 genera), Brzeski 1998 (key for 5 genera), Brzeski 1981 (key for 8 genera)
Subfamily Anguininae Nicoll, 1935: Krall 1991 (key for 4 gall-inducing genera), Chizhov \& Subbotin 1990 (key for 4 genera)

Afrina Brzeski, 1981

Anguina Scopoli, 1777: Andrássy 2007 (key for 4 European species), Brzeski 1998 (key for 4 European species), Krall 1991 (key for 10 species), Chizhov \& Subbotin 1990 (key for species)

Diptenchus Khan, Chawla \& Seshadri, 1969

Ditylenchus Filipjev, 1936: Hashemi \& Karegar 2019 (compendium and key for 63 species), Esmaeili \& Heydari, 2016 (key for 27 species including Nothotylenchus species from Iran), Andrássy 2007 (key for 27 European species), Das \& Bajaj 2005, Brzeski 1998 (key for 29 European species, compendium for 76 species including Nothotylenchus species), Viscardi \& Brzeski 1993 (computerized key), Brzeski 1991 (compendium for 80 species and redescription of 20 species), Sturhan \& Brzeski 1991 (compendium for 82 species including Nothotylenchus species), Thorne \& Malek 1968 (key for 6 species).

Ficotylus Davies, Ye, Giblin-Davis \& Thomas, 2009 Indoditylenchus Sinha, Ghoudhury \& Baqri, 1985

Litylenchus Davies, Zhao, Alexander \& Riley, 2011

Mesoanguina Chizhov \& Subbotin, 1985: Krall 1991 (key for 8 species), Chizhov \& Subbotin 1990 (key for species)

Nothanguina Whitehead, 1959

Nothotylenchus Thorne, 1941: Hashemi \& Karegar 2020 (compendium and key for 41 species), Andrássy 2007 (key for 27 European species), Thorne \& Malek 1968 (key for 4 species),

Orrina Brzeski, 1981

Pseudhalenchus Tarjan, 1958: Brzeski 1998 (key for 4 European species), Grewal 1991 (key for 4 species)

Pterotylenchus Siddiqi \& Lenné, 1984

Safianema Siddiqi, 1980

Subanguina Paramonov, 1967: Brzeski 1998 (key for 4 European species)

Subfamily Halenchinae Jairajpuri \& Siddiqi, 1969

Halenchus N.A. Cobb in M.V. Cobb, 1933

Family Neotylenchidae Thorne, 1941: Sumenkova, 1989 (key for genera and species).

Subfamily Fergusobiinae Goodey, 1963

Fergusobia Currie, 1937 (Christie, 1941): Davies et 
al. 2014 (key for Australian species)

Subfamily Gymnotylenchinae Siddiqi, 1980

Gymnotylenchus Siddiqi, 1961

Subfamily Neotylenchinae Thorne, 1941: Andrássy 2007 (key for 7 genera)

Anguillonema Fuch, 1938: Yaghoubi et al. 2018 (key for 3 species)

Hexatyleus Goodey, 1926: Andrássy 2007 (key for 3 European species)

Deladenus Thorne, 1941: Andrássy 2007 (key for 10 European species)

Subfamily Rubzovinematinae Slobodyanyuk, 1999

Rubzovinema Slobodyanyuk, 1991

Family Sphaerulariidae Lubbock, 1861 (Skarbilovich, 1947)

Subfamily Paurodontinae Thorne, 1941

Abursanema Yaghoubi, Pourjam, Pedram, Siddiqi \& Atighi, 2014

Bealius Massey \& Hinds, 1970

Luella Massey, 1974

Misticius Massey, 1967

Neomisticius Siddiqi, 1986

Paurodontella Husain \& Khan, 1968: Iqbal et al. 2010 (key for 10 species)

Paurodontoides Jairajpuri \& Siddiqi, 1969

Paurodontus Thorne, 1941

Subfamily Sphaerulariinae Lubbock, 1861

Prothallonema Christie, 1938: Geraert et al. 1984 (key for 12 species)

Sphaerularia Dufour, 1837

Tripius Chitwood, 1935

Veleshkinema Miraeiz, Heydari, Álvarez-Ortega, Pedram \& Atighi, 2015

Class Enoplea Inglis, 1983

Subclass Dorylaimia Inglis, 1983

Order Dorylaimida Pearse, 1942

Suborder Dorylaimina Pearse, 1942

Superfamily Dorylaimoidea Thorne, 1935: Vinciguerra 2006 (key for 10 families)

Family Longidoridae Thorne, 1935: Pedram 2018 (key for 8 genera) [in Persian], Decraemer \& Chaves 2013 (key for 2 subfamilies, compendium for 7 genera), Hunt 1993 (key for 3 subfamilies)
Subfamily Longidorinae Thorne, 1935: Andrássy 2007 (key for 8 genera), Taylor \& Brown 1997 (key for some taxa), Hunt 1993 (key for 3 genera)

Australodorus Coomans, Olmos, Casella \& Chaves, 2004

Longidoroides Khan, Chawla \& Saha, 1978

Longidorus Micoletzky, 1922: Ye \& Robbins 2004 (compendium for 137 species), Loof \& Chen 1999 (compendium for 13 species, supplement for Chen et al. 1997), Chen et al. 1997 (compendium for 103 species), Rey et al. 1988 (computerized key for 65 species), Romanenko 1978, Zheng et al. 2001 (key for 12 species from China), Xu et al. 2018 (key for 15 species from China).

Paralongidorus Siddiqi, Hooper \& Khan, 1963: Escuer \& Arias 1997 (compendium for 70 species)

Paraxiphidorus Coomans \& Chaves, 1995

Xiphidorus Monteiro, 1976: Decraemer et al. 1996 (key for 6 species)

Subfamily Xiphinematinae Dalmasso, 1969

Xiphinema Cobb, 1913: Lamberti et al. 2004 (key and compendium for 49 species in $X$. americanum group), Coomans et al. 2001 (compendium for over 100 species), Lamberti et al. 2000 (compendium for 51 species in $X$. americanum group), Loof et al. 1996, Robbins et al. 1996 (compendium for 114 species based on juveniles), Lamberti \& Carone 1991 (key for 38 species in X. americanum group), Loof \& Luc 1990 (compendium for 172 species in the genus, excluding X. americanum group), Loof \& Luc 1983, Kohn \& Sher 1972 (key for 50 species), Ganguly et al. 2000 (key to 12 species of group 1), Sen et al. 2010 (key to 14 species for mono-opisthodelphic species).

\section{Subclass Enoplia Pearse, 1942 \\ Order Triplonchida Cobb, 1920}

Suborder Diphtherophorina Coomans \& Loof, 1970

Superfamily Diphtherophoroidea Micoletzky, 1922

Family Trichodoridae Thorne, 1935: Niknam \& Jabbari 2018 (key for 4 genera) [in Persian], Decraemer \& Chaves 2012 (key for 6 genera), Andrássy 2007 (key for 5 genera), Almeida \& Decraemer 2005 (key for genera and species) [in Portuguese], Decraemer \& Baujard 1998 (compendium for 90 species in the family), Decraemer 1995 (key for 4 genera), Hunt 1993 (key for 4 genera), Decraemer 1991 (compendium for 4 genera), Loof 1975, Siddiqi 1974.

Allotrichodorus Rodriguez-M, Sher \& Siddiqi, 1978: Rashid et al. 1985 (key for 7 species based on females 
and males), Decraemer 1980 (key for 2 species), Rodriguez-M et al. 1978 (key for 2 species).

\section{Ecuadorus Siddiqi, 2002}

Monotrichodorus Andrássy, 1976: Decraemer 1980 (key for 2 species), Rodriguez-M et al. 1978 (key for 2 species).

Paratrichodorus Siddiqi, 1974: Decraemer \& Chaves 2013 (key for 8 virus-vector species), Decraemer 1995 (key for 31 species based on females and males), Andrássy 2007 (key for 13 European species), Decraemer 1980 (key for 16 species based on females and males), Siddiqi 1973.

Trichodorus Cobb, 1913: Decraemer \& Chaves 2013 (key for 4 virus-vector species), Zahedi et al. 2009 (key for 5 Iranian species), Andrássy 2007 (key for 18 European species), Decraemer \& Baujard 1998a (key and compendium for 90 species), Decraemer \& Baujard 1998b (additions and corrections to Decraemer \& Baujard 1998a), Taylor \& Brawn 1997, Decraemer 1995 (key for 48 species based on females and males), De Waele \& Brzeski 1995 (key for 46 species), Decraemer 1980 (key for 22 species based on females and males), Esser 1971.

\section{REFERENCES}

Allen, M.W. \& S.A. Sher (1967). Taxonomic problems concerning the phytoparasitic nematodes. Annual Review of Phytopathology 5: 247-264.

Allen, M.W. (1940). Anomyctus xenurus, a new genus and species of Tylenchoidea (Nematoda). Proceedings of the Helminthological Society of Washington 7: 96-98.

Allen, M.W. (1955). A review of the nematode genus Tylenchorhynchus. University of California Publications in Zoology, Berkeley and Los Angeles 129-165.

Almeida, M.T. M., \& W. Decraemer (2005). Trichodoridae, família de nematóides vetores de vírus. Revisão Anual de Patologia de Plantas (RAPP).

Anderson, R.V. \& E.S. Eveleigh (1982). Description of Helicorylenchus amplius n. sp. and a key to the Canadian species of the genus (Nematoda: Hoplolaimidae). Canadian Journal of Zoology 60: 318321

Anderson, R.V. \& D.J. Hooper (1980). Diagnostic value of vagina structure in the taxonomy of Aphelenchus Bastian, 1865 (Nematoda: Aphelenchidae) with a description of $A$. (Anaphelenchus) isomerus n. subgen., n. sp. Canadian Journal of Zoology 58: 924-928.

Anderson, R.V. \& R.H. Mulvey (1979). Plant-parasitic Nematodes in Canada. Part 1: An illustrated key to the genera. Monograph No. 20 Biosystematics Research Institute, Ottawa, Ontario, 152 p.

Anderson, R.V. (1979). A supplemental key to species Helicotylenchus Steiner, 1945 (Nematoda: Hoplolaimidae) described since 1972 and a description of $\mathrm{H}$. oscephalus n. sp. Canadian Journal of Zoology 57: 337-342.

Anderson, R.V. (1983). Morphological characteristics of Hoplolaimus indicus Sher, 1963 in Canada, a parasite of wild rice. Journal of Nematology 15: 367-369.

Andrássy, I. (1982). The genera and species of the family Tylenchidae arley, 1880 (Nematoda). The genus Coslenchus Siddiqi, 1978. Acto
Zoologica Academiae Scientarum Hungaricae 28: 193-232.

Andrássy, I. (2001). Some species of curious genera of the Class Secementia (Nematoda). International Journal of Nematology 11: 137-149.

Andrássy, I. (1954). Revision der Gattung Tylenchus Bastian, 1865 (Tylenchidae, Nematoda). Acta Zoologica Hungaricae 1: 5-42.

Andrássy, I. (1958). Hoplolaimus tylenchiformis Daday, 1905 (Syn. H. coronatus Cobb, 1923) und die Gattungen der Unterfamilie Hoplolaiminae Filipjev, 1936. Nematologica 3: 44-56.

Andrássy, I. (1965). Verzeichnis und Bestimmungsschliissel der Arten der Nematoden- Gattungen Criconemoides Taylor, 1936 und Mesocriconema n. gen. Opuscula Zoologica Instituti Zoosystematici Universitatis Budapestinensis 5: 153-171

Andrássy, I. (1973). 100 nematode species new for the fauna of Hungary. Opuscula Zoologica Budapest 11: 7-48.

Andrássy, I. (1976). Evolution as a basis for the systematization of nematodes. Pitman Publ. Co, London, 288pp.

Andrássy, I. (1979). Revision of the subfamily Criconematinae Taylor, 1936 (Nematoda). Opuscula Zoologica Instituti Zoosystematici Universitatis Budapestinensis 16: 11-57.

Andrássy, I. (1979). The genera and species of the family Tylenchidae Orley, 1880 (Nematoda). The genus Tylenchus Bastian, 1865. Acta Zoologica Academiae Scientarum Hungaricae 25: 1-33.

Andrássy, I. (1980). The genera and species of the family Tylenchidae Orley, 1880 (Nematoda). The genera Aglenchus (Andrassy, 1954) Meyl, 1961, Miculenchus Andrassy, 1959, and Polenchus gen.n. Acta Zoologica Academiae Scientarum Hungaricae 26: 1-20

Andrássy, I. (1984). The genera and species of the family Tylenchidae arley, 1880 (Nematoda). The genera Cephalenchus (Goodey, 1962) Golden, 1971 and Allotylenchus gen.n. Acta Zoologica Academiae Scientarum Hungaricae 30: 1-28.

Andrássy, I. (2007). Free-living nematodes of Hungary (Nematoda Errantia) II. Pedozoologica Hungarica No. 4. Hungarian Natural History Museum, Budapest, 496pp

Arias, M. (1970). Paratrophuros loofi n. gen., n. sp. (Tylenchidae), from Spain. Nematologica 16: 47-50.

Asghari, R., E. Pourjam, R. Heydari \& Z.Q. Zhao (2012) Laimaphelenchus persicus n. sp. (Nematoda: Aphelenchoididae) from Iran. Zootaxa 3325: 59-67.

Bajaj, H.K. (1997). Description of Cervoannulatus graminus gen.n., sp.n. and Psilenchus mixus sp.n. (Tylenchida) trom Haryana, India. Indian Journal of Nematology 27: 156-161.

Baldwin, J.G., E.C. Bernard \& M. Mundo-Ocampo (1989). Four new species of Heteroderidae including Ekphymatodera n. gen. from California. Journal of Nematology 21: 48-68.

Baldwin, J.G. \& A.H. Bell (1981). Pararotylenchus n. gen. (Pararotylenchinae n. subfam., Hoplolaimidae) with six new species and two new combinations. Journal of Nematology 13: 111-128.

Baldwin, J.G. \& M. Mundo-Ocampo (1991). Heteroderinae, cyst and non-cyst-forming nematodes, pp. 275-362. In: Nickle W.R. (ed). Manual of agricultural nematology. Marcel Dekker, New York, 1052 pp.

Baldwin, J.G., \& L.P. Schouest (1990). Comparative detailed morphology of the Heteroderinae Filipjev \& Schuurmans Stekhoven, 1941, sensu Luc et al. (1988): Phylogenetic systematics and revised classification. Systematic Parasitology 15: 81-106.

Baldwin, J.G., M. Luc \& A.H. Bell (1983). Contribution to the study of the genus Pratylenchoides Winslow (Nematoda: Tylenchida). Revue de Nématologie 6: 111-125

Bastian C.H. (1865). Monograph on the Anguillulidae, or free nematodes, marine, land and freshwater; with descriptions of 100 new species. Transactions of the Linnean Society 25: 73-184.

Baujard, P. (1984). Comments on the subfamily Ektaphelenchinae Paramonov, L964 and proposal for Ektaphelenchoides n. gen. (Nematoda: Aphelenchoididae). Revue de Nématologie 7: 147-171.

Baujard, P., P. Castillo, M. Doucet, B. Martiny \& D. Mounport (1994). Taxonomic studies on the genus Aorolaimus Sher, 1963 (Nemata, Hoplolaimidae). 1. Bibliographic analysis and tentative key to species. Fundamental and applied nematology 17(2): 103-115. 
Bell, N.L. (2002). A computerised identification key for 30 genera of plant parasitic nematodes. New Zealand Plant Protectio 55: 287290.

Bello, A., R. Mahajan \& M.C. Zancada (1987). Amplimerlinius hornensis sp. n. (Nematoda: Merliniinae) with notes on A. siddiqii from Spain. Revue de Nématologie 10: 295-298.

Bernard, E.C., Z.A. Handoo, T.O. Powers, P.A. Donald \& R.D. Heinz (2010). Vittatidera zeaphila (Nematoda: Heteroderidae), a new genus and species of cyst nematode parasitic on corn (Zea mays). Journal of Nematology 42 (2): 139-150.

Bernard, E.C. \& T.L. Niblack (1982). Review of Hoplotylus s'Jacob, (Nematoda: Pratylenchidae). Nematologica 28: 101-109.

Bittencourt, C. \& C.S. Huang (1986). Brazilian Peltamigratus Sher, 1964 (Nematoda: Hoplolaimidae), with descriptions of six new species. Revue de Nématologie 9(1): 3-24.

Boag, B. \& D.J. Hooper (1981). Rotylenchus ouensensis n. sp. (Nematoda: Hoplolaimidae) from the British Isles. Systematic Parasitology 3: 119-125.

Boag, B. \& M.S. Jairajpuri (1985). Helicotylenchus scoticus n.sp. and a conspectus of the genus Helicotylenchus Steiner, 1945 (Tylenchida: Nematoda). Systematic Parasitology 7: 47-58.

Bongers, T. (1988). De nematoden van Nederland. Stichting Uitgeverij Koninklijke Nederl. Natuurhist. Ver., Utrecht, The Netherlands, 408pp.

Brzeski, M.W. (1974). Taxonomy of Hemicycliophorinae (Nematoda: Tylenchida). Zeszyty Problemowe Postepow Nauk Rolniczych 154: 237-330.

Brzeski, M.W. (1981). The genera of Anguinidae (Nematoda: Tylenchida). Revue de Nématologie 4: 23-24.

Brzeski, M.W. (1982). Taxonomy of Ottolenchus Husain \& Khan 1967 and description of Coslenchus polonicus sp.n. (Nematoda: Tylenchidae). Revue de Nématologie 5: 71-77.

Brzeski, M.W. (1985). Four new species of Tylenchidae (Nematoda) Nematologica 31(4): 424-432.

Brzeski, M.W. (1987). Taxonomic notes on Coslenchus Siddiqi, 1978 (Nematoda: Tylenchidae). Annales Zoologici 40: 417-436

Brzeski, M.W. (1991). Review of the genus Ditylenchus Filipjev, 1936 (Nematoda: Anguinidae). Revue de Nématologie 14: 9-59.

Brzeski, M.W. (1991). Taxonomy of Geocenamus Thorne \& Malek 1968 (Nematoda: Belonolaimidae). Nematologica 37: 125-173.

Brzeski, M.W. (1996). On the genus Eutylenchus Cobb, 1913 (Nematoda: Tylenchidae). Nematologica 42: 1-8.

Brzeski, M.W. (1998). Nematodes of Tylenchina in Poland and temperate Europe. Muzeum and Institute of Zoology, Polish Academy of Sciences, Warszawa, Poland. 397 pp.

Brzeski, M.W. \& T.S. Ivanova (1978). Taxonomic notes on Hemicycliophora de Man (Nematoda: Hemicycliophoridae) Nematologica Mediteranea 6: 147-162.

Brzeski, M.W. \& C.M. Dolinski (1998). Compendium of the genus Tylenchorhynchus Cobb, 1913 sensu lato (Nematoda: Belonolaimidae). Russian Journal of Nematology 6: 189-199.

Brzeski, M.W. \& M.R. Sauer (1982). Scanning electron micrography of some Tylenchidae and Boleodoridae and reappraisal of the Boleodoridae. Nematologica 28(4): 437-446.

Brzeski, M.W., Y.E. Choi \& P.A.A Loof. (2002). Compendium of the genus Criconemoides Taylor, 1936 (Nematoda: Criconematidae) Nematology 4: 325-339.

Brzeski, M.W., P.A.A. Loof \& Y.E. Choi (2002). Compendium of the genus Mesocriconema Andrássy, 1965 (Nematoda: Criconematidae). Nematology 4: 341-360.

Burrows, P.R., W.M. Wouts, A. Schoemaker \& D. Sturhan (1995) Heterodera spinicauda sp. n. (Nematoda: Heteroderidae) from mud flats in the Netherlands, with a key to the species of the H. avenae Group. Nematologica 41(1-4): 575-583.

Café-Filho, A.C. \& C.S. Huang (1989). Description of Pratylenchus pseudofallax n. sp. with a key to the species of the genus Pratylenchus Fil. (Tylenchida: Pratylenchidae). Revue de Nématologie 12: 7-15.

Carta, L.K., A.M. Skantar, Z.A. Handoo \& M.A. Baynes (2011) Supplemental description of Paraphelenchus acontioides
(Tylenchida: Aphelenchidae, Paraphelenchinae), with ribosomal DNA trees and a morphometric compendium of female Paraphelenchus. Nematology 13(8): 887-899.

Castillo, P. \& N. Vovlas (2005). Bionomics and Identification of the genus Rotylenchus (Nematoda: Hoplolaimidae). Brill Publishing. 377 pp.

Castillo, P. \& N. Vovlas (2007). Pratylenchus (Nematoda: Pratylenchidae): diagnosis, biology, pathogenecity and management (Nematology monographs and perspectives: volume 6). Brill Academic Publisher. $529 \mathrm{pp}$

Castillo, P., M.R. Siddiqi \& A. Gomez-Barcina (1989). Studies on the genus Paratrophurus Arias (Nematoda: Tylenchina) with descriptions of two new species. Nematologia mediterranea 17: 83-95.

Castillo, P., J. Stanley, R.N. Inserra \& R.H. Manzanilla-López (2012). Pratylenchidae, the lesion nematodes, pp. 411-478. In: Manzanilla-López, R.H. \& N. Marbán-Mendoza (eds). Practical Plant Nematology. Mundi-Prensa Espana, Madrid, 883 pp.

Castillo, P., N. Vovlas, A. Gomez-Barcina \& F. Lamberti (1994). The plant parasitic nematodes Rotylenchus (A monograph). Supplement. Nematologia Mediterranea 21: 200.

Chen, Q.W. \& P.A.A. Loof (1999). A revised polytomous key for the identification of species of the genus Longidorus Micoletzky, 1922 (Nematoda: Dorylaimoidea). Supplement 1. Nematology 1(1): 55-

Chen, Q., D.J. Hooper, P.A.A. Loof \& J. Xu (1997). A revised polytomous key for the identification of species of the genus Longidorus Micoletzky, 1922 (Nematoda: Dorylaimoidea). Fundamental and applied Nematology 20(1): 15-28.

Chitambar, J.J. \& H. Ferris (2005). Geocenamus angelescresti n. sp., a diagnostic key and compendium to the species of the genus Geocenamus Thorne \& Malek, 1968 (Nematoda: Belonolaimidae). Journal of Nematology 37: 429-437.

Chitambar, J.J. \& S.A. Subbotin (2014). Systematics of the sheath nematodes of the superfamily Hemicycliophoroidea. Nematology monographs and perspectives, volume 10. Brill Publication, LeidenBoston. 732 pp.

Chitwood, B.G. \& W. Birchfleld (1957). A new genus, Hemicriconemoides (Criconematidae: Tylenchina). Proceedings of the Helminthological Society of Washington 24: 80-86.

Chitwood, B.G. (1933). On some nematodes of the superfamily Rhabditoidea and their status as parasites of reptiles and amphibians. Journal of the Washington Academy of Sciences 23(11): 508-520.

Chitwood, B.G., C.I. Hannon \& R.P. Esser (1956). A new nematode genus, Meloidodera, linking the genera Heterodera and Meloidogyne. Phytopathology 48(5): 264-266.

Chitwood, B.G. (1935). Nomenclatorial notes, 1. Proceedings of the Helminthological Society of Washington 2: 51-54.

Chitwood, B.G. (1950). An outline classification of nematodes. In: Chitwood B.G. and M.B. Chitwood. (eds.) An Introduction to Nematology. Monumental Printing Co., Baltimore, 12-25.

Chizhov, V.N. \& S.A. Subbotin (1985). Revision of the family Anguininae (Nematoda, Tylenchida) based on biological characteristics. Zoologichesky Zhurnal 64: 1476-1486.

Chizhov, V.N. \& S.A. Subbotin (1990). Plant-parasitic nematodes of the subfamily Anguininae (Tylenchida, Nematoda). Morphology, trophic specialization, systematics. Zoologicheskii Zhurnal 69(4): 15-16.

Choi, Y.E. \& E. Geraert (1973). Description of Meloinema kerongense n.g., n.sp. (Nematoda: Meloidogynidae) from Korea. Nematologica 19: 334-341.

Christie, J.R. (1938). Two nematodes associated with decaying citrus fruit. Proceedings of the Helminthological Society of Washington 5 : 29-33.

Cid del Prado Vera, I. (1991). Description of Meloidodera Mexicana n. sp. (Nemata: Heteroderinae) with key to species. Revue de Nématologie 14: 537-542.

Cid del Prado Vera, I. \& B.L. Miranda (2008). A second cyst-forming nematode parasite of barley (Hordeum vulgare L. var. Esmeralda) 
from Mexico. Nematropica 38: 105-114.

Cid del Prado Vera, I. \& S.A. Subbotin (2012). Belonolaimus malucero sp. n. (Tylenchida: Belonolaimidae) from a tropical forest in Mexico and key to the species of Belonolaimus. Nematropica 42: 201-210.

Cid del Prado Vera, I., \& M. Talavera (2012). Criconematoidea. Pp. 479-519 in R. H. Manzanilla-Lopez and N. Marbán-Mendoza, eds. Practical plant nematology. Estado de México, México: Biblioteca Básica de Agricultura.

Cid del Prado Vera, I. \& S.A. Subbotin (2014). A new cyst nematode, Cactodera torreyanae sp. n. (Tylenchida: Heteroderidae), parasitising romerito, Suaeda torreyana, in Texcoco, Mexico. Nematology 16(2): 163-174.

Cid del Prado Vera, I., B.F. Lownsbery \& A.R. Maggenti (1983). Rhizonema sequoiae n. gen. n. sp. from coast redwood Sequoia sempervirens (Don) Endl. Journal of Nematology 15: 460-467.

Cobb, N.A. (1913). Notes on Mononchas and Tylenchulus. Journal of the Washington Academy of Sciences 3: 287-288.

Cobb, N.A. (1914). The North American free-living freshwater nematodes. Contributions to a science of Nematology. Transactions of the American Microscopical Society 33: 69-134.

Cobb, N.A. (1920). One hundred new nemas. (Type species of 100 new genera). Contributions to a science of nematology 9: 217-343.

Cobb, N.A. (1927). Note on a new nerna, Aphelenchus retusus, with a proposed division of Aphelenchas into three subgenera. Read before Helminth. Soc. Washington, Oct. 1.6, 1926. Journal of Parasitology 14: $57-58$.

Cobb, M.V. (1933). New nemic genera and species, with taxonomic notes. The Journal of Parasitology 20(2): 81-94.

Colbran, R.C. (1965). Studies of plant and soil nematodes. 11 Carphodorus bilineatus n.g., n.sp. (Nematoda: Dolichodorinae) from eucalypt forest in Queensland. Queensland Journal of Agricultural and Animal Science 22: 481-484.

Colbran, R.C. (1966). Studies of plant and soil nematodes. 12. The eucalypt cystoid nematode Cryphodera eucalypti n. g., n. sp (Nematoda: Heteroderidae), a parasite of eucalypts in Queensland. Queensland Journal of Agricultural and Animal Science 23: 41-47.

Coomans, A. \& E. Chaves (1995). Paraxiphidorus michelluci ng, n. sp. from Argentina (Nematoda: Longidoridae). Fundamental and Applied Nematology 18(3): 303-306.

Coomans, A. \& P.A.A. Loof (1970). Morphology and taxonomy of Bathyodontina (Dorylaimida). Nematologica 16(2): 180-196.

Coomans, A., R. Huys, J. Heyns \& M. Luc (2001). Character analysis, phylogeny and biogeography of the genus Xiphinema Cobb, 1913 (Nematoda: Longidoridae). Annales Sciences Zoologiques (volume: 287), $239 \mathrm{pp}$

Coomans, A., I. Olmos, E. Casella \& E. Chaves (2004). Australodorus enigmaticus n. g, n. sp. (Nematoda: Longidoridae) from Uruguay. Nematology 6(2): 183-191.

Corbett, D.C.M. (1964). Central African Nematodes. I. Ecphyadophora quadralata n.sp. and two species of Ecphyadophoroides n.gen. (Nematoda: Neotylenchidae). Nematologica 10: 121-130.

Crozzoli, R. \& F. Lamberti (2001). Known and new species of Mesocriconema Andrássy, 1965 (Nematoda: Criconematidae) from Venezuela. Russian Journal of Nematology 9(2): 85-106.

Crozzoli, R. \& F. Lamberti (2002). Species of Criconema Hofmanner \& Menzel, 1914 and Ogma Southern, 1914 occurring in Venezuela, with description of Ogma araguaensis sp. n. (Nematoda: Criconematidae). Russian Journal of Nematology 10: 89-98.

Currie, G.A. (1937). Galls on Eucalyptus trees. A new type of association between flies and nematodes. Proceedings of the Linnean Society of New South Wales 62: 147-174.

Dalmasso, A. (1969). Anatomical studies and taxonomy of the genera Xiphinema, Longidorus and Paralongidorus (Nematoda: Dorylaimidae). Memoires du Museum National d'Histoire Naturelle Nouvelle serie, Serie A Zoologie 61: 33-82.

Das, D. \& H.K. Bajaj (2005). New and known species of Ditylenchus Filipjev, 1936 from Haryana, India. Indian Journal of Nematology 35: 11-23.

Dasgupta D.R., D.J. Raski \& S.D. van Gundy (1969). Revision of the genus Hemicriconemoides Chitwood and Birchfield, 1957 (Nematoda: Criconematidae). Journal of Nematology 1: 126-145.

Davies, K.A., F. Bartholomaeus, L. Lisnawita, N. Kanzaki \& R.M. Giblin-Davis (2010). Schistonchus (Aphelenchoididae) from Ficus (Moraceae) in Australia, with description of S. aculeata sp. n. Nematology 12(6): 935-958.

Davies, K.A., W. Ye, R. Giblin-Davis \& K. Thomas (2009). Ficotylus congestae gen. n., sp. n. (Anguinata), from Ficus congesta (Moraceae) sycones in Australia. Nematology 11(1): 63-75.

Davies, K.A., Z.Q. Zhao, B. Alexander \& I. Riley (2011). Litylenchus coprosma gen. n., sp. n. (Tylenchida: Anguinata), from leaves of Coprosma repens (Rubiaceae) in New Zealand. Nematology 13(1): 29-44.

Davies, K.A., W. Ye, R.M. Giblin-Davis, G.S. Taylor, M. Hodda \& W.K. Thomas (2014). Nematodes from galls on Myrtaceae. VII. Fergusobia from 'leafy'leaf bud galls in Australia, with re-description of Fergusobia tumifaciens (Currie 1937) Wachek 1955 and descriptions of Fergusobia planchonianae n. sp. and Fergusobia viminalisae n. sp. Zootaxa 3856(4): 529-554.

De Grisse, A.T. (1969). Contribution to the morphology and the systematics of the Criconematidae (Taylor, 1936) Thorne, 1949. (Thesis, Gent, Belgium).

De Grisse, A. \& P.A.A. Loof (1965). Revision of the genus Criconemoides (Nematoda). Mededelingen van de Landbouwhogeschool en de Opzoekingsstations van de Staat te Gent 30: 577-603.

de Guiran, G. (1967). Description de Radopholoides litoralis n.g., n.sp. (Nematoda: Pratylenchinae). Nematologica 13: 231-234.

de Guiran, G. \& G. Germani (1968). Brachydorus tenuis n.gen., n.sp. (Nematoda: Dolichodorinae) associe a Ravenala madagascariensis sur la cote est malgache. Nematologica 14: 447-452.

De Ley, P. \& M.L. Blaxter (2004). A new system for Nematoda: combining morphological characters with molecular trees, and translating clades into ranks and taxa, pp. 633-653 in Cook, R. \& Hunt, D.J. (eds). Proceedings of the fourth international congress of Nematology, 8-13 June 2002, Tenerife, Spain. Nematology monographs and perspectives 2. Leiden, the Netherlands: Brill.

De Ley, P. \& A. Coomans (1996). Terrestrial nematodes of the Galapagos archipelago: 6. Punchaulus gemellensis, a new genus and species of Aphelenchina (Tylenchida). Fundamental and Applied Nematology 19(2): 159-165.

De Ley, P. \& M.L. Blaxter (2002). Systematic Position and Phylogeny. pp. 1-30. In D. L. Lee (ed). The Biology of Nematodes. Taylor \& Francis, London, UK, 648 pp.

De Man, J.G. (1921). Nouvelles recherches sur les nematodes libres terricoles de la Hollande. Capita Zoologica 1: 1-62.

De Waele, D. \& M.W. Brzeski (1995). Trichodorus altaicus sp. n. (Nematoda: Trichodoridae) and a key to the species of the genus Trichodorus. Fundamental Applied of Nematology 18: 181-187.

Decraemer, W. (1980). Systematics of the Trichodoridae (Nematoda) with keys to their species. Revue de Nématologie 3: 81-99.

Decraemer, W. (1991). Stubby root and virus vector nematodes: Trichodorus, Paratrichodorus, Allotrichodorus and Monotrichodorus. In: Nickle, W. R. (Ed.). Manual of agricultural nematology. Marcel Dekker, Inc. Pp: 587-625.

Decraemer, W. (1995). The Family Trichodoridae: Stubby Root and Virus Vector Nematodes. Developments in Plant Pathology, 6. Dordrecht: Kluwer Academic Publishers, 361 pp.

Decraemer, W. (2013). The family Trichodoridae: Stubby root and virus vector nematodes (Vol. 6). Springer Science \& Business Media.

Decraemer, W. \& P. Baujard (1998a). Taxonomic status of Paratrichodorus faisalabadensis Nasira \& Maqbool, 1994 and P. psidii Nasira \& Maqbool, 1994 (Nematoda: Triplonchida). Fundamental Applied of Nematology 21: 33-36.

Decraemer, W. \& P. Baujaed (1998b). A polytomous key for the identification of species of the family Trichodoridae Thorne, 1935 (Nematoda: Triplonchida). Fundamental Applied of Nematology 21(1): 37-62.

Decraemer, W. \& E. Chaves (2012). Longidoridae and Trichodoridae, pp. 579-617. In R. H. Manzanilla-López \& N. Marbán-Mendoza 
(eds). Practical plant nematology. Montecillo, Mexico: Bibliotheca Basica de Agricultura.

Decraemer, W., M. Luc, M.E. Doucet \& A. Coomans (1996). Study on the genus Xiphidorus Monteiro, 1976 (Nematoda: Longidoridae). Fundamental and Applied Nematology 19(3): 207-226.

Diederich, J., R. Fortuner, R. \& J. Milton (1991). Nemisys: nematode identification system, pp. 1-42. In R. Fortuner (ed). Advances in computer methods for systematic biology: artificial intelliegence, database systems, computer vision. Baltimore, MD: Johns Hopkins University Press, 574 pp.

Doucet, M.E. (1996). New data on Psilenchus hilarus Siddiqi, 1963 and description of two new species of Psilenchus de Man, 1921 (Nematoda: Tylenchida) from Argentina. Fundamental and Applied Nematology 19: 449-461.

Dufour, J.M.L. (1837). Recherches sur quelq entozoaires et larves parasites des insects orthoptbres et hymenopteres. Annales des sciences naturelles. Zoologie et biologie animale Annales des Sciences Naturelles Zoologie 2(7): 5-20.

Ebsary, B.A. (1979). Description of Criconemoides pleriannulatus n. sp. (Nematoda: Criconematidae) and a key to the species of Criconemoides. Canadian Journal of Zoology 57: 1-5.

Ebsary, B.A. (1982). Bakernema yukonense n. sp. (Nematoda: Criconematidae) with keys to the species of Criconemella and Discocriconemella. Canadian Journal of Zoology 60: 3033-3047.

Ebsary, B.A. \& V. Anderson (1982). Two new species of Hirschmaniella Luc and Goody, 1963 (Nematoda: Pratylenchidae) with a key to the nominal species. Canadian Journal of Zoology 60: 530-534.

Ebsary, B.A. \& E.S. Eveleigh (1983). Meloidogyne aquatilis n. sp. (Nematoda: Meloidogynidae) from Spartina peainata with a key to the Canadian species of Meloidogyne. Journal of Nematology 15 349-353.

Ebsary, B.A. (1991). Catalog of the Order Tylenchida (Nematoda). Publication 1869/B. Ottawa, Canada: Canada Communication Group-Publishing, $196 \mathrm{pp}$.

Ebsary, B.A. (1981). Neobakernema n. gen. (Nematoda: Criconematidae) with an emendation of Bakernema Wu, 1964. Canadian Journal of Zoology 59: 2215-2216.

Eisenback, J.D. (2002). Identification guides for the most common genera of plant-parasitic nematodes. Mactode Publications, $35 \mathrm{pp}$.

Eisenback, J.D. \& H.H. Triantaphyllou (1991). Root-knot nematodes: Meloidogyne species and races, pp: 191-274. In: Nickle, W. R. (ed) Manual of agricultural nematology. Marcel Dekker, Inc., 1052 pp.

Eisenback, J.D., H. Hirschmann, J.N. Sasser \& A.C. Triantaphyllou (1981). A guide to the four most common species of root-knot nematodes [Meloidogyne species] with a pictorial key. A cooperative publication of Deprtment of Plant Pathology and Genetics, North Carolina State University and US Agency for International Development. Raleigh, North Carolina, 48 pp.

Eroshenko, A.S. (1976). Rotylenchus alpinus n. sp. from the mountain tundra of the Kamchatka. Parazitologiya 10: 463-465

Escuer, M. \& M. Arias (1997). Paralongidorus iberis sp. n. and P. monegrensis sp. n. from Spain with a polytomous key to the species of the genus Paralongidorus Siddiqi, Hooper \& Khan, 1963 (Nematoda: Longidoridae). Fundamental and Applied Nematology 20(2): 135-148.

Esmaeili, M. \& R. Heydari (2016). New record of three species of Ditylenchus Filipjev, 1936 (Nematoda: Anguinidae), with a key to the species reported from Iran. Journal of Crop Protection 5(4): 565-579.

Esser, R.P. \& N. Vovlas (1990). A diagnostic compendium to the genus Hemicriconemoides (Tylenchida: Criconematidae). Soil and Crop Science Society of Florida Proceedings 49: 211-219.

Esser, R.P. (1971). A compendium of the genus Trichodorus (Dorylaimoidea: Diphtherophoridae). Proceedings of the Soil and Crop Science Society of Florida 31: 244-253.

Esser, R.P. (1981). Verutus volvingentis n. gen., n. sp. (Heteroderidae: Tylenchida) in Verutinae n. subf., a phytoparasitic nematode infesting buttonweed in Florida. Proceedings of the Helminthological Society of Washington 48: 220-240.
Esser, R.P. (1989). An illustrated diagnostic compendium of members of the family Dolichodoridae Chitwood, 1950. Proceedings of the Soil and Crop Science Society of Florida 48: 173-179.

Esser, R.P. (1992). A diagnostic compendium to species included in Paratylenchinae Thorne, 1949 and Tylenchocriconematinae Raski \& Siddiqui, 1975 (Nematoda: Criconematoidea). Nematologica 38: 146-163.

Erum, Y.I., R. Musarrat \& F. Shahina (2011). Description of Neodolichorhynchus indicus sp. n. from Pakistan, with a key to species of the subgenus Neodolichorhynchus (Mulkorhynchus). Journal of Nematode Morphology and Systematics 14(1): 55-62.

Filipjev, I.N. \& J.H.S. Stekhoven (1941). A Manual of Agricultural Helminthology. Brill, Leiden, 878 pp.

Filipjev, I.N. (1934). The classification of the free living nematodes and their relation to the parasitic nematodes. Smithsonian Miscellaneous Collections 89: 63 pp.

Firoza, K. \& M.A. Maqbool (1994). A diagnostic compendium of the genus Helicotylenchus Steiner, 1945 (Nematoda: Hoplolaimidae). Pakistan Journal of Nematology 12: 11-50.

Fischer, M. (1894). Uber eine Clematis krankheit. Bericht aus dem Physiolischen Laboratorium des Landwirthschaftlichen, Instituts der Universitat Halle 11: 1-11.

Fortuner, R. \& Y. Wong (1984). Review of the genus Helicotylenchus Steiner, 1945. 1: a computer program for identification of the species. Revue de Nématologie 7: 385-392.

Fotedar, D.N. \& Z.A. Handoo (1978). A revised scheme of classification to the order Tylenchida Thorne, 1949 (Nematoda). Journal of Science, University of Kashmir 3: 55-82.

Fotedar, D.N. \& V. Kaul (1985). On some species of the genus Helicotylnchus Steiner, 1945 (Hoplolaimidae: Nematoda), common plant parasitic nematodes in Kashmir, India. Indian Journal of Nematology 15: 9-13.

Frederick, J.J. \& A.C. Tarjan (1989). A compendium of the genus Pratylenchus Filipjev, 1936 (Nemata: Pratylenchidae). Revue de Nématologie 12: 243-256.

Fuchs, A.G. (1929). Die Parasiten einiger Russel und Borkenkafer. Zeitschrift für Parasitenkunde 2: 248-285.

Fuchs, A.G. (1931). Die Genera: 1. Rhabditolaimus Fuchs. 2. Neodiplogaster Cobb. 3. Tylenchodon Fuchs. Zentralblatt ges Forstw 57: 177-194.

Fuchs, A.G. (1937). Neue parasitische und halbparasitische Nematoden bei Borkenkäfern und einige andere Nematoden. I. Teil die Parasiten der Waldgartner Myelophilus piniperda L. und minor Hartig und die Genera Rhabditis Dujardin, 1845 und Aphelenchus Bastian, 1865. Zoologische Jahrbücher. Abteilung für Systematik, Geographie und Biologie der Tiere 70: 291-380

Fuchs, A.G. (1938). Neue Parasiten und Halbparasiten bei Borkenkäfem und einige andere Nematoden II, III, u. IV, Teil. Zoologische Jahrbücher. Abteilung für Systematik, Geographie und Biologie der Tiere 72: 123-190.

Ganguly, S., M. Singh, \& D.L.C. Procter (2000). Two new species of Xiphinema Cobb. 1913 (Nematoda: Dorylaimida) from high altitudes of Bhutan alongwith a key and compendium to the species of Group 1 sensu Loof \& Luc, 1990. Indian Journal of Nematology 30(2): 147156.

Ganguly, S., M. Lal \& K.S. Rathour (2013). A check-list of globally known species of Tylenchorhynchus Cobb, 1913 along with compendium of the Indian species. Indian Journal of Nematology 43(1): 47-60.

Ganguly, S., K.S. Rathour \& M. Lal (2013). A check-list and compendium of globally known species of Helicotylenchus Steiner, 1945. Indian Journal of Nematology 43: 127-141.

Geraert, E. (1965). The genus Paratylenchus. Nematologica 11: 301334.

Geraert, E. (1971). Observations on the genera Boleodorus and Boleodoroides (Nematoda: Tylenchida). Nematologica 17: 263-276.

Geraert, E. (1991). Tylenchidae in agricultural soils, pp. 795-825. In: Nickle, W.R. (ed). Manual of Agricultural Nematology. Marcel Dekker, New York, 1052 pp. 
Geraert, E. (2008). The Tylenchidae of the World, identification of the family Tylenchidae (Nematoda: Tylenchida). Academia Press, Ghent, Belgium, $540 \mathrm{pp}$.

Geraert, E. (2010). The Criconematidae of the World, Identification of the family Criconematidae (Nematoda). Academia Press, Gent, Belgium, $615 \mathrm{pp}$.

Geraert, E. (2011). The Dolichodoridae of the World, identification of the family Dolichodoridae (Nematoda: Tylenchida). Academia Press, Ghent, Belgium, 520 pp.

Geraert, E. (2013). The Pratylenchidae of the World, identification of the family Pratylenchidae (Nematoda: Tylenchida). Academia Press, Ghent, Belgium, $430 \mathrm{pp}$

Geraert, E. \& S. Barooti (1996). Four Rotylenchus from Iran, with a key to the species. Nematologica 42: 503-520.

Geraert, E. \& D.J. Raski (1988). Study of some Aglenchus and Coslenchus species (Nemata: Tylenchida). Nematologica 34: 6-46.

Geraert, E. \& D.J. Raski (1986). Unusual Malenchus species (Nematoda: Tylenchidae). Nematologica 32: 27-55.

Geraert, E., D.J. Raski \& Y.E. Choi (1984). A study of Stictylus intermedius $\mathrm{n}$. comb. with a review of the genus (Nematoda: Tylenchida). Nematologica 30: 161-171.

Germani, G. \& M. Luc (1970). Contributions á l'étude du genre Hemicriconemoides. Cahiers ORSTOM Série Biologie 11: 133-150.

Germani, G. (1978). Morphological and biometrical characters of 3 West African species of Rotylenchulus (Nematoda: Tylenchida). Revue de Nématology 1: 241-250.

Germani, G., J.G. Baldwin, A.H. Bell \& X.Y. Wu (1985). Revision of the genus Scutellonema Andràssy, 1958 (Nematoda: Tylenchida). Revue de Nématologie 8: 289-320.

Germani, G., M. Luc \& J.G. Baldwin (1984). A new Rotylenchulinae: Senegalonema sorghi n. gen., n. sp. (Nematoda: Tylenchida). Revue de Nématologie 7: 49-56

Ghaderi, R. (2019). Systematics of cystoid nematodes. Scholars Press, Riga, Latvia. 124 pp.

Ghaderi, R. \& A. Karegar (2014). Contribution to a revision of the genus Pratylenchoides Winslow, 1958 (Nematoda: Merliniidae), with redescription of $P$. erzurumensis Yüksel, 1977 from Iran. Zootaxa 3900: 339-369.

Ghaderi, R. \& A. Karegar (2014). Description of Amplimerlinius uramanatiensis sp. $\mathrm{n}$. (Nematoda: Merliniidae) and observations on three other species of the genus from Iran. Zootaxa 3869: 17-32.

Ghaderi, R. \& A. Karegar (2016). One new and three known species of Geocenamus Thorne \& Malek, 1968 (Nematoda: Merliniidae) from Iran. Zootaxa 4079: 151-178.

Ghaderi, R. \& G. Karssen (2020). An updated checklist of Meloidogyne Göldi, 1887 species, with a diagnostic compendium for secondstage juveniles and males. Journal of Crop Protection 9(2): 183-193.

Ghaderi, R., E. Geraert \& A. Karegar (2016). The Tylenchulidae of the world; identification of the family Tylenchulidae (Nematoda: Tylenchida). Ghent, Belgium, Academia Press, 453 pp.

Ghaderi, R., A. Karegar, E. Miraeiz \& K. Hashemi (2017). Comparative morphology of the anterior end of selected taxa of Merliniidae Siddiqi, 1971 (Nematoda: Tylenchoidea), with morphological characterisation of two species and taxonomic keys to several genera. Zootaxa 4300: 571-588.

Ghaderi, R., L. Kashi \& A. Karegar (2014). Contribution to the study of the genus Paratylenchus Micoletzky, 1922 sensu lato (Nematoda: Tylenchulidae). Zootaxa 3841: 151-187.

Gharahkhani, A., E. Pourjam, J. Abolafia, P. Castillo \& M. Pedram (2020). Sigmolenchus sinuosus n. gen., n. sp. (Tylenchidae: Ecphyadophorinae), a new member of the family. Nematology 1 (aop): 1-13

Giblin-Davis, R.M., N. Kanzaki \& K.A. Davies (2013). Nematodes that ride insects: unforeseen consequences of arriving species. Florida Entomologist 96: 770-780.

Goeldi, E.A. (1892). Relatorio sobre a molestia do cafeeiro na provincia do Rio de Janeiro. Archivos do Museo Nacional, Rio de Janeiro, 8,7$121+4$ plates, 44 figures and a map.

Golden, A.M. (1971). Classihcation of the genera and higher categories of the order Tylenchida (Nematoda), pp. 191-232. In: B.M. Zuckerman et al. (ed). Vol. I, Plant Parasitic Nematodes, Academic Press, New York, 359 pp.

Golden, A.M. (1986). Morphology and identification of cyst nematodes, pp. 23-45. In: F. Lamberti \& C. E. Tylor (eds). Cyst nematodes. Plenum Press, New York, 478 pp.

Golden, A.M. \& W. Friedman (1964). Some taxonomic studies on the genus Criconema (Nematoda: Criconematidae). Proceedings of the Helminthological Society of Washington 31: 47-59.

Golden, A.M. \& H.J. Jensen (1974). Nacobbodera chitwoodi n. gen., n. sp. (Nacobbidae: Nematoda) on Douglas fir in Oregon. Journal of Nematology 6: 30-37

Goodey, J.B. (1951). The "hemizonid", a hitherto unrecorded structure in members of the Tylenchoidea. Journal of Helminthology 25: 3336.

Goodey, J.B. (1962). Tylenchus (Cephalenchus) megacephalus n.sbg., n.sp. Nematologica 7: 331-333.

Goodey, T. (1926). Hexatylus viviparus gen. et sp. nov., a nematode found in a diseased potato tuber. Journal of Helminthology 4: 27-30.

Goodey, T. (1963). Soil and freshwater nematodes. London: Methuen. 2nd ed. revised by J.B. Goodey, 544 pp.

Graney, L.S.O. \& G.W. Bird (1990). Descriptions and comparative morphology of Cactodera milleri n. sp. (Nematoda: Heteroderidae) and Cactodera cacti with a review and key to the genus Cactodera. Journal of Nematology 22: 457-480.

Grewal, P.S. (1991). Descriptions of Pseudhalenchus leevalleyensis sp. nov. and $P$. siddiqii sp. nov. (Nematoda: Tylenchida) from England and notes on $P$. minutus from Turkey and Yugoslavia. Afro-Asian Journal of Nematology 1(1): 57-63.

Grove, C., J. Smart \& N.B. Khuong (1985). Dolichodorus miradvulvus n. sp. (Nematoda: Tylenchida) with a key to species. Journal of Nematology 17: 29-37.

Guirado, D.J., M.M. Navarro, R.G. Liébanas, B.B. Landa \& P. Castillo (2007). Morphological and molecular characterization of a new awl nematode, Dolichodorus mediterraneus sp. n. (Nematoda: Dolichodoridae), from Spain. Nematology 9: 189-199.

Handoo, Z.A. (2000). A key and diagnostic compendium to the species of the genus Tylenchorhynchus Cobb, 1913 (Nematoda: belonolaimidae). Journal of Nematology 32: 20-34.

Handoo, Z.A. (2002). A key and compendium to species of the Heterodera avenae group (Nematoda: Heteroderidae). Journal of Nematology 34(3): 250-256.

Handoo, Z.A. \& A.M. Golden (1989). A key and diagnostic compendium to the species of the genus Pratylenchus Filipjev, 1936 (lesion nematodes). Journal of Nematology 21: 202-218.

Handoo, Z.A. \& A.M. Golden (1992). A key and Diagnostic Compendium to the Species of the Genus Hoplolaimus Dady, 1905 (Nematoda: Hoplolaimidae). Journal of Nematology 24(1): 45-53.

Handoo, Z.A., A. Khan \& S. Islam (2007). A key and diagnostic compendium to the species of the genus Merlinius Siddiqi, 1970 (Nematoda: Tylenchida) with description of Merlinius khuzdarensis n. sp. associated with date palm. Nematology 9: 251-260

Hashemi, K. \& A. Karegar (2019). Description of Ditylenchus paraparvus n. sp. from Iran with an updated list of Ditylenchus Filipjev, 1936 (Nematoda: Anguinidae). Zootaxa 4651: 85-113.

Hashemi, K. \& A. Karegar (2020). New and known species of Nothotylenchus Thorne, 1941 (Nematoda: Anguinidae) from Iran with an updated list of species. Zootaxa 4729 (4): 482-500.

Hashim, (1984). Re-diagnosis and a key to the species of Neolobocriconema Mehta \& Raski, 1971 (Nematoda: Tylenchida), with a description of $N$. olearum n. sp. from Jordan. Systematic Parasitology 6: 69-73.

Hewlett, T.E. \& A.C. Tarjan (1983). Monographs: Synopsis of the genus Meloidogyne Goeldi, 1887. Nematropica 13: 79-102.

Heyns, J. \& E. Van Den Berg (1996). Neothada hades n.sp. from South Africa, with notes on the genus and a key to the species (Nematoda: Tylenchidae). South African Journal of Zoology 31: 165-169.

Hodda, M. (2011). Phylum Nematoda Cobb 1932. In: Zhang, Z.-Q.(Ed.) Animal biodiversity: An outline of higher-level classification and 
survey of taxonomic richness. Zootaxa 3148(1): 63-95.

Hofmänner, B. \& R. Menzel (1914). Neue Arten freilebenderNematoden aus der Schweiz. Zoologischer Anzeiger 44: 80-91.

Hooper, D.J. (1978). The Tylenchorhynchidae. The identification of stunt nematodes Tylenchorhynchinae, Merliniinae and Trophurinae especially those in Western Europe. In: A manual prepared for the Workshop sponsored by the Nematology Group of the Association of Applied Biologists held at Rothamsted Experimental Station, Part II, $75 \mathrm{pp}$.

Hopper, B.E. \& E.J. Cairns (1959). Taxonomic keys to plant, soil and aquatic nematodes. Auburn, AL, USA, Alabama Polytechnic Institute, $176 \mathrm{pp}$

Hosseinvand, M., A. Eskandari, P. Castillo, J. Palomares-Rius \& R Ghaderi (2020). Systematic position of Atetylenchus Khan, 1973 (Nematoda: Tylenchidae) with description of two new species. Nematology 22: 1155-1167.

Hosseinvand, M., A. Eskandari, S. Ganjkhanloo, R. Ghaderi, P. Castillo \& J.E. Palomares-Rius (2020). Taxonomical considerations and molecular phylogeny of the closely related genera Bitylenchus, Sauertylenchus and Tylenchorhynchus (Nematoda: Telotylenchinae), with one new and four known species from Iran. Journal of Helminthology 94: e197: 1-25.

Huang, C.S. \& D.I. Raski (1986). Some Tylenchidae from Brazi with description of Cucullitylenchus amazonensis gen. n., sp. $n$. (Tylenchoidea: Nemata). Revue de Nématologie 9: 209-219.

Hunt, D.J. (1993). Aphelenchida, Longidoridae \& Trichodoridae: Their systematics and bionomics. Wallingford, UK: CABI Publishing, 352 pp.

Hunt, D.J. (1995). Four new species of the genus Rhigonema Cobb, 1898 (Nematoda: Rhigonematida: Rhigonematidae) parasitic in diplopods from Papua, New Guinea. Nematologia Mediterranea 23: 217-234.

Hunt, D.J. (1980). Acugutturus parasiticus n. g., n. sp., a remarkable ectoparasitic aphelenchoid nematode from Periplaneta omericana (L.), with proposal of Acugutturinae n. subf. Systematic Parasitology 1: 167-170.

Hunt, D.J. \& Z.A. Handoo (2009). Taxonomy, identification and principal species, pp. 55-97. In: Perry, R.N. \& M. Moens (eds). Root Knot Nematodes. CAB International, Wallingford, UK, 520 pp.

Hunt, D.J., W. Bert \& M.R. Siddiqi (2013). Tylenchidae and Dolichodoridae, pp. 209-250. In: Manzanilla-López, R.H. \& N MarbánMendoza (eds). Practical Plant Nematology. Montecillo, Mexico, Bibliotheca Basica de Agricultura, $883 \mathrm{pp}$.

Hunt, D.J., Bridge, J. Sher \& J.E. Machon (1989). On Achlysiella, a new genus of obese Pratylenchidae (Nematoda: Tylenchoidea). Revue de Nématologie 12: 401-407.

Husain S.I. \& A.M. Khan (1967). On the status of the genera of the superfamily Aphelenchoidea (Fuchs, 1937) Thome, 1949 with the descriptions of six new species of nematodes from India. Proceedings of the Helminthological Society of Washington 34 167-174.

Husain, S.I. \& A.M. Khan (1967). A new subfamily, a new subgenus and eight new species of nematodes from India belonging to superfamily Tylenchoidea. Proceedings of the Helminthological Society of Washington 34(2): 175-186.

Husain, Z. \& S.H. Khan (1968). A new species of the genus Eutylenchus Cobb, 1913 (Nematoda: Atylenchidae) from India. Annals Epiphyte 19: 331-334

Husseinvand, M., M. Abdollahi \& A. Karegar (2016). Description of Aglenchus Microstylus n. sp. (Nematoda, Tylenchidae) from Iran with a modified key to the species of the genus. Nematropica 46 38-44.

Inglis, W.G. (1983). An outline classification of the Phylum Nematoda. Australian Journal of Zoology 31: 245-255.

Inserra, R.N., N. Vovlas, J.H. O’Bannon \& R.P. Esser (1988). Tylenchulus graminis $\mathrm{n}$. sp. and T. palustris $\mathrm{n}$. sp. (Tylenchulidae), from native flora of Florida, with notes on $T$. semipenetrans and $T$. furcus. Journal of Nematology 20: 266-287.

Iqbal, E., N. Kazi, Z. Handoo \& S. Fayyaz (2010). Two new species of
Paurodontella Husain \& Khan, 1968 (Nematoda: Sphaerulariidae) associated with wheat and a diagnostic compendium to the genus. Nematology 12(2): 181-192.

Ivanova, T. \& E. Krall (1985). Nematodes of the family Meloidoderidae (Nematoda: Hoplolaimoidea). 1. Bursadera n.g. and the relationship of some families of Hoplolaimoidea. Eesti NSV Tead. Akademie Toim Biologia 34: 135-143.

Jairajpuri, M.S. (1971). On Scutylenchus mamillatus (Tobar-Jimenez, 1966) n. comb. (Abstract. National Academy of Sciences, India, $40^{\text {th }}$ Session, p. 18.

Jairajpuri, M.S. (1982). Some studies on Tylenchorhynchinae: the subgenus Bitylenchus Filipjev, 1934, with description of Tylenchorhynchus (Bitylenchus) depresus n. sp. and a key to species of Bitylenchus. [34th International Symposium Fytofann. en Fytiat. Gent, 1.982. Deel II]. Mededelingen Faculteit Landbouwwetenschappen Rijksuniversiteit Gent 47: 765-770

Jairajpuri, M.S. \& Q.H. Baqri (1973). Nematodes of high altitudes in India. I. Four new species of Tylenchida. Nematologica 19(1): 19-30.

Jairajpuri, M.S. \& D.J. Hunt (1984). The taxonomy of Tylenchorhynchinae (Nematoda: Tylenchida) with longitudinal lines and ridges. Systematic Parasitology 6(4): 261-268.

Jairajpuri, M.S. \& M.R. Siddiqi (1969). Paurodontoides n. gen (Paurodontidae) with an outline classification of Neotylenchoidea $\mathrm{n}$. rank. Nematologica 15: $281-288$.

Jatala, P. (1991). Reniform and false root-knot nematodes, Rotylenchulus and Nacobbus spp., pp: 509-528. In: Nickle, W. R. (ed). Manual of agricultural nematology. Marcel Dekker, Inc. 1052 $\mathrm{pp}$

Jepson, S.B. (1983). Identification of Meloidogyne: a general assessment and a comparison of male morphology using light microscopy, with a key to 24 species. Revue de Nématologie 6: 291-309.

Jepson, S.B. (1987). Identification of root-knot nematodes (Meloidogyne species). CAB International. The Cambridge News Ltd., Aberystwyth, U.K., 265 pp.

Kakuliya, G.A. (1967). A new nematode genus Devibursaphelenchus gen. n. (Nematoda: Aphelenchoididae). Bulletin of the Academy of Sciences of the Georgian SSR 47: 439-443.

Kanzaki, N., \& R. Tanaka (2013). Sheraphelenchus sucus n. sp.(Tylenchina: Aphelenchoididae) isolated from sap flow of Quercus serrata in Japan. Nematology 15(8): 975-990.

Kanzaki, N. \& R.M. Giblin-Davis (2012). Aphelenchoidea, pp. 161-208. In: N. M. Mendoza, R. Manzanilla-López, \& D. Hunt (eds). Practical plant nematology. London, UK: CAB International, 883 pp.

Kanzaki, N., R.M. Giblin-Davis, R.H. Scheffrahn, J.C. Barbara \& K.A. Davies (2009). Pseudaphelenchus yukiae n. gen., n. sp. (Tylenchina: Aphelenchoididae) associated with Cylindrotermes macrognathus (Termitidae: Termitinae) in La Selva, Costa Rica. Nematology 11(6): 869-881.

Kanzaki, N., H.F. Li, Y.C. Lan \& R.M. Giblin-Davis (2014) Description of two Pseudaphelenchus species (Tylenchomorpha: Aphelenchoididae) associated with Asian termites and proposal of Tylenaphelenchinae n. subfam. Nematology 16(8): 963-978.

Karegar, A. \& E. Geraert (1997). The genus Neopsilenchus Thorne \& Malek, 1968 (Nematoda: Tylenchidae). Nematologica, 43, 307-326.

Karegar, A. \& E. Geraert (1998). The genus Basiria Siddiqi, 1959 (Nematoda: Tylenchidae) IV. General discussion, genus diagnosis and key to the species. Nematologica 44: 1-13.

Karssen, G. (2002). The plant-parasitic nematode genus Meloidogyne Goldi, 1892 (Tylenchida) in Europe. Leiden, The Netherlands, Brill Academic Publishers, $157 \mathrm{pp}$.

Karssen, G. \& A. Van Aelst (1999). Description of Cryphodera brinkmani n. sp. (Nematoda: Heteroderidae), a parasite of Pinus thunbergii Parlatore from Japan, including a key to the species of the genus Cryphodera Colbran, 1966. Nematology 1: 121-130.

Karssen, G. \& T. Van Hoenselaar (1998). Revision of the genus Meloidogyne Göldi, 1892 (Nematoda: Heteroderidae) in Europe. Nematologica 44(6): 713-788.

Kashi, L. \& A. Karegar (2018). Classification of plant parasitic 
nematodes. In: Ghaderi, R., Kashi, L. \& Karegar, A. (Eds). Plantparasitic nematodes in Iran. Shiraz, Iran, Marjaeelm \& Iranian Society of Nematology, pp. 27-37.

Khan E., M.L. Chawla \& M. Saha (1976). Criconematoidea (Nematoda: Tylenchida) from India, with descriptions of nine new species, two new genera and a family. Indian Journal of Nematology 5 (1975) 70-100.

Khan, E., M.L. Chawla \& M. Saha (1978). Comments on the classification of the Longidoroidea (Nematoda) with description of three new species. Indian Journal of Nematology 6(1): 47-62.

Khan, E., M.L. Chawla, \& A.R. Seshadri (1969). Diptenchus indicus n. gen., n. sp. (Nematoda: Tylenchidae) from soil around roots of grapevine from Delhi, India. Nematologica 15: 337-340.

Khan, F.A. \& Khan, A.M. (1975). Two new species of Basiroides Thome \& Malek, 1968 (Nematoda: Psilenchinae) from Uttar Pradesh. Indian Journal of Nematology 4 (1974): 194-198.

Khan, S.H. (1964). Sakia typica n.g., n.sp. (Nematoda: Neotylenchidae) from North India. Proceedings $5^{r t} \& 52^{\text {nd }}$ Indian Science Congress III, p. 467.

Khan, S.H. (1973). On the proposal for Neothada n. gen. (Nematoda: Tylenchinae). Proceedings of the National Academy of Sciences, India, Biological Sciences 43: 17-18.

Kheiri, A. (1970). Two new species in the family Tylenchidae (Nematoda) from Iran, with a key to Psilenchus. Nematologica 16: 359-368.

Kheiri, A. (1972). Tylenchus (Irantylenchus) clavidorus n.sp. and Merlinius camelliae n.sp. (Tylenchida: Nematoda) from Iran Nematologica 18: 339-346.

Khun, K., W. Decraemer, M. Couvreur, G. Karssen, H. Steel \& W. Bert (2015). Deceptive morphological variation in Hirschmanniella mucronata (Nematoda: Pratylenchidae) and a polytomous key to the genus. Nematology 17(4): 377-400.

Kirjanova, E.S.\& E.S. Poghossian (1973). Redescription of Meloidoderito kirjanovae Pogosyan, 1966 (Nematoda: Meloidoderitidae n. fam.). Parazitologiya 7: 280-285.

Kleynhans, K.P.N. \& P. Cadet (1994). Trophurus deboeri n.sp. from sugarcane soil in Barbados and key to the species of the genus Trophurus Loof, 1956 (Nemata: Belonolaimidae). Fundamental and Applied Nematology 17(3): 225-230.

Kolombia, Y., G. Karssen, N. Viaene, P.L. Kumar, L. Joos, D.L. Coyne \& W. Bert (2017). Morphological and molecular characterization of Scutellonema species from yam (Dioscorea spp.) and a key to the species of the genus. Nematology 19: 751-787.

Krall, E.L. (1990). Root parasitic nematodes family Hoplolaimidae. E. J. Brill Publishing Company, Leiden, 580 pp.

Krall, E.L. (1991). Wheat and grass nematodes: Anguina, Subanguina, and related genera, pp: 721-760. In: Nickle, W.R. (ed). Manual of agricultural nematology. Marcel Dekker, Inc. 1052 pp.

Krall, E.L. \& H. Krall (1978). Revision of the plant nematodes of the family Heteroderidae on the basis of the trophic specialization of these parasites and their co-evolution with their host plants 1 . In: Fitogel'mintologicheskie issledovaniya. Moscow, USSR; Nauka. 3956.

Krall, E.L., L.M. Shagalina \& T.S. Ivanova (1988). A new desert-inhabiting genus and species of nematodes Camelodera eremophila gen. $\mathrm{n}$., sp. $\mathrm{n}$. (Nematoda, Heteroderidae, Ataloderinae). Proceedings of the Estonian Academy of Sciences, Biology 37: 27-35

Kulinich, O., M. Mota, P. Vieira \& A. Ryss (2005). A synopsis of the genus Bursaphelenchus Fuchs, 1937 (Aphelenchida: Parasitaphelenchidae) with keys to species. Nematology 7(3): 393-458.

Lamberti, F. \& M. Carone (1991). A dichotomous key for the identification of species of Xiphinema (Nematoda: Dorylaimida) within the $X$. americanum-group. Nematologia Mediterranea 19(2): 341-348.

Lamberti, F. \& C.E. Tylor (1986). Cyst Nematodes. Plenum Press. New York, $478 \mathrm{pp}$

Lamberti, F., S. Hockland, A. Agostinelli, M. Moens \& D.J.F. Brown (2004). The Xiphinema americanum group. III. Keys to species identification. Nematologia mediterranea 32(1): 53-56.
Lamberti, F., S. Molinari, M. Moens \& D.J.F. Brown (2000). The Xiphinema americanum group. I. Putative species, their geographical occurrence and distribution, and regional polytomous identification keys for the group. Russian Journal of Nematology 8: 65-84.

Lewis, S.A. \& A.M. Golden (1980). Description and SEM observations of Dolichodorus marylandicus n. sp. with a key to species of Dolichodorus. Journal of Nematology 13: 128-135.

Lewis, S.A. \& A.M. Golden (1981). Description of Trilineellus clathrocutis n. gen; n. sp. (Tylenchorhynchinae: Tylenchida Thome, 1949) with a key to species and observations on Tylenchorhynchus sensu stricto. Journal of Nematology 13: 135-141.

Lewis, S.A., R. T. Robbins, W. Ye, Z.A. Handoo \& A. M. Golden (1999). Some important key to species of selected genera of plant-parasitic nematodes. Society of Nematologists Nematology Newsletter 45(3): 9-22.

Linford, M.B. \& J.M. Oliveira (1940). Rotylenchulus reniformis novo gen., n. sp., a nematode parasite of roots, Proceedings of the Helminthological Society of Washington 7(1): 35-42.

Loof, P.A.A. (1956). Trophurus, a new tylenchid genus (Nematoda). Verslagen en Mededelingen Plantenziektekundige Dienst, Jaarboek 129 (1955): 191-195.

Loof, P.A.A. (1958). Some remarks on the status of the subfamily Dolichodorinae, with descriptions of Macrotrophurus arbusticola n.gen., n.sp. (Nematoda: Tylenchidae). Nematologica 3: 301-307

Loof, P.A.A. (1968). Morphological observations on Criconema boettgeri (Meyl, 1954) De Grisse and Loof, 1965. Mededelingen van de Rijksfaculteit Landbouwwetenschappen Gent 33: 659-668.

Loof, P.A.A. (1975). Taxonomy of Trichodoridae, pp. 103-127. In: Lamberti, F. (ed). Nematode vectors of plant viruses. Springer, Boston, M.A., $460 \mathrm{pp}$.

Loof, P.A.A. (1976). The genera Hemicycliophora de Man, 1921 and Caloosia Siddiqui \& Goodey, 1963. Mededelingen Faculteit Landbouwhogeschool Rijksuniversiteit Gent 41: 1023-1029.

Loof, P.A.A. (1978). The genus Pratylenchus Filipjev, 1936 (Nematoda: Pratylenchidae): a review of its anatomy, morphology, distribution, systematics and identification. Sveriges Landbruksuniversiteit Viixtskyddsrapporter 5: 1-12.

Loof, P.A.A. (1991). The family Pratylenchidae Thorne, 1949, pp: 363-421. In: Nickle, W. R. (ed). Manual of agricultural nematology. Marcel Dekker, Inc. 1052 pp.

Loof, P.A.A. \& Q. Chen (1999). A revised polytomous key for the identification of species of the genus Longidorus Micoletzky, 1922 (Nematoda: Dorylaimoidea). Supplement 1. Nematology 1: 55-59.

Loof, P.A.A. \& A. De Grisse (1989). Taxonomic and nomenclatorial observations on the genus Criconemella De Grisse \& Loof, 1965 sensu Luc \& Raski, 1981. Mededelingen Faculteit Landbouwwetenschappen Rijksuniversiteit Gent 54: 53-74.

Loof, P.A.A. M. \& Luc (1990). A revised polytomous key for the identification of species of the genus Xiphinema Cobb, 1913 (Nematoda: Longidoridae) with exclusion of the $X$. americanumgroup. Systematic Parasitology 16: 35-66.

Loof, P.A.A. M.\& Luc (1993). A revised polytomous key for the identification of species of the genus Xiphinema Cobb, 1913 (Nematoda: Longidoridae) with the exclusion of the $X$. americanumgroup: Supplement 1. Systematic Parasitology 24: 185-189

Loof, P.A.A. \& R.D. Sharma (1975). Dolichodorus minor n. sp. (Nematoda: Dolichodoridae) with a key to the genus Dolichodorus. Revista Theobroma CEPEC, Itabuna, Brasil 5: 35-41.

Loof, P.A.A., M. Luc \& P. Baujard (1996). A revised polytomous key for the identification of species of the genus Xiphinema Cobb, 1913 (Nematoda: Longidoridae) with exclusion of the $X$. americanum group: Supplement 2. Systematic Parasitology 33: 23-29.

Lubbock, J. (1861). On Sphaerularia bombi. Natural History Review 1: 44-57

Luc, M. \& J.B. Goodey (1964). Hirschmanniella nom. nov. for Hirschmannia. Nematologica 9: 471.

Luc, M., D.P. Taylor \& P. Cadet (1978). Description of a new tropical Heteroderidae, Hylonema ivorense n. gen., n. sp., and a new outlook on the family Heteroderidae (Nematoda: Tylenchida). Revue de 
Nématology 1: 73-86.

Maas P.W.T., P.A.A. Loof \& A. De Grisse (1971). Nothocriconemoides lineolatus (n. gen., n. sp. Nematoda: Criconematidae). Mededelingen Fakulteil Landbouwwetenschappen Gent 36: 711-715.

Mai, W.F. \& H.H. Lyon (1975). Pictorial key to genera of plant-parasitic nematodes, 4th Ed., Ithaca and London, Cornell University Press, 219 pp.

Manzanilla-López, R.H. \& N. Marbán-Mendoza (2012). Practical Plant Nematology. Colegio de Postgraduados and Mundi-Prensa, Biblioteca Básica de Agricultura, 883 pp.

Maqbool, M. A. (1982). Description of Quinisulcius solani n. sp. (Nematoda: Tylenchorhynchidae) with a key to the species and data on Scutylenchus koreanus from Pakistan. Journal of Nematology 14: 221-225.

Massese, C.S.L. \& G. Germani, (2000). Description de quatre nouvelles especes et de quatre populations de Rotylenchus (Nematoda: Hoplolaimidae). Proposition d'une cle tabulaire. Nematology 2(7) 699-718.

Massey, C.L. (1967). Nematodes associated with tree-infesting insects: Paurodontidae new family and Misticiinae new subfamily with a description of one new genus and four new species. Canadian Journal of Zoology 45: 779-786.

Massey, C.L. (1974). Biology and taxonomy of nematode parasites and associates of bark beetles in the United States. Agricultura Handbook No. 446, Washington: USDA, For. Serv. 1-233.

Massey, C.L. \& T.E. Hinds (1970). Nematodes from aspen cankers in Colorado and New Mexico. Canadian Journal of Zoology 48: 97-108.

Maria, M., Y. Fang, J. Gu \& H. Li, (2016). Redescription of Bursaphelenchus parapinasteri (Tylenchina: Aphelenchoididae) isolated from Pinus thunbergii in China with a key to the Hofmannigroup. Nematology 18(8): 933-947

Meagher, J.W. (1964). Tylodorus acuminatus n.gen., n.sp. (Nematoda: Tylenchinae) from Eucalyptus forest in Australia. Nematologica 9 635-640.

Meagher, J.W. (1968). Acontylus vipriensis n. g., n. sp. (Nematoda: Hoplolaimidae) parasitic on Eucalyptus sp. in Australia. Nematologica 14: 94-100.

Mehta, U.K. \& D.J. Raski (1971). Revision of the genus Criconema Hofmanner and Menzel, 1914 and other related genera (Criconematidae: Nematoda). Indian Journal of Nematology 1: 145-198.

Mekete, T., A. Dababat, N. Sekora, F. Akyazi \& E. Abebe (2012) Identification key for agriculturally important plant parasitic nematodes Prepared for the International Nematode Diagnosis and Identification Course 2012-A manual for nematology. Mexico, DF: CIMMYT, $39 \mathrm{pp}$

Micoletzky, H. (1922). Die freilebenden erd-Nematoden: mit besonderer Berücksichtigung der Steiermark und der Bukowina, zugleich mit einer Revision sämtlicher nicht mariner freilebender Nematoden in Form von Genus-Beschreibungen und Bestimmungsschlüsseln. Archiv für Naturgeschichte (1921): 1-650.

Minagawa, N. (1993). Taxonomic studies of Criconematidae (Nematoda: Tylenchida) of Japan. 4. Genus Ogma: Part 2. Bulletin of the National Institute of AgroEnvironmental Sciences 9: 53-152.

Miraeiz, E. (2018). Nematodes of the superfamily Aphelenchoidea. In: Ghaderi, R., Kashi, L. \& Karegar, A. (Eds). Plant-parasitic nematodes in Iran. Shiraz, Iran, Marjaeelm \& Iranian Society of Nematology, pp. 39-112.

Miraeiz, E., R. Heydari, S. Alvarez-Ortega, M. Pedram \& M.R. Atighi (2015). Molecular and morphological characterization of Veleshkinema iranicum n. gen., n. sp. (Nematoda: Hexatylina, Sphaerularioidea) from Iran. Zootaxa 4000 (5): 531-546.

Mizukubo, T. \& N. Minagawa (1985). The genus Coslenchus Siddiqi, 1978 (Tylenchidae: Nematoda) from Japan. II. Synonymy of Coslenchus over Cosaglenchus and Paktylenchus based on the Phylogenetic Relationships and a Key to the Species. Japanese Journal of Nematology 15: 14-25

Monteiro, A.R. \& L.G.E. Lordello (1977). Dois novos nematoides encontrados associados á cana-de-açúcar. Revista de Agricultura,
Piracicaba 52: 5-11.

Monteiro, A.R. (1976). Xiphidorus yepesara n. gen., n. sp. (Nemata: Longidoridae) from Brazil. Nematologia Mediterranea 4(1): 1-6.

Mulk, M.M. \& M.S. Jairajpuri (1974). Proposal ofa new genus Dolichorhynchus and a new species Dolichorhynchus nigericus (Nematoda: Dolichodoridae). Indian Journal of Zoology 2(1): 15-18

Mulk, M.M., \& Siddiqi, M.R. (1982). Three new species of hoplolaimid nematodes from South America. Indian Journal of Nematology 12(1): 124-131.

Mulvey, R.H. (1972). Identification of Heterodera cysts by terminal and cone top structures. Canadian Journal of Zoology 50(10): 12771292

Mulvey, R.H. \& B.A. Ebsary (1980). Dolichodera fluvialis n. gen., n. sp. (Nematoda: Heteroderidae) from Quebec, Canada. Canadian Journal of Zoology 58: 1697-1702.

Mulvey, R.H. \& M. Golden (1983). An illustrated key to the cystforming genera and species of Heteroderidae in the Western hemisphere with species morphometrics and distribution. Journal of Nematology 15: 1-59.

Mulvey, R.H. \& A.R. Stone (1976). Description of Punaodera matadorensis n. gen., n. sp. (Nematoda: Heteroderidae) from Saskatchewan with lists of species and generic diagnoses of Globodera (n. rank), Heterodera, and Sarisoderq. Canadian Journal of Zoology 54: 772-785.

Nama, H.S. \& G.R. Soni (1981). Taxonomy of some species of the genus Aphelenchus Bastian, 1865 (Aphelenchoidea) with a key. Proceeding of the Indian Academy of Parasitology, 2(2): 107-110.

Nguyen, N.C. \& D.T. Anh (2019). Tree new species of the spiral Nematode genus Helicotylenchus Steiner, 1945 (Nematoda: Hoplolaimidae) from Vietnam. Tap Chi Sinh Hoc 41(2): 12-27.

Nickle, W.R. (1970). Description of Entaphelenchidae fam. n. Roveaphelenchus jonesi gen. n., sp. n. and Sheraphelenchus entomophagus gen. n., sp. n. (Nematoda: Aphelenchoidea). Proceedings of the Helminthological Society of Washington 37: 105-109.

Nickle, W.R. (1991). Manual of agricultural nematology. New York, NY: Marcel Dekker, $1052 \mathrm{pp}$.

Nicoll, W. (1935). Rhabditida. Anguinidae. VI. Vermes, Zoological Record 72: 105

Niknam, G. \& H. Jabbari (2018). The family Trichodoridae, pp. 667680. In: Ghaderi, R., Kashi, L. \& Karegar, A. (eds). Plant-parasitic nematodes in Iran. Shiraz, Iran, Marjaeelm \& Iranian Society of Nematology, 758 pp.

Örley, L. (1880). Az anguillulidak maganrajza. A kir.m. termeszettudom. Tersulat altal a bugatdijjal jutalmazott palyamii. Termeszetr Fuz 4:16-50.

Oro, V., N., Milovanović \& V. Petrović (2015). Nano-morfologija Laimaphelenchus belgradiensis (nematoda: aphelenchoididae) i ključ za vrste roda Laimaphelenchus. Zaštita bilja/Plant Protection 66 (1): 32-37.

Orton Williams, K.J. (1982). A new genus and four new species of Criconematidae (Nematoda) from the Pacific. Systematic Parasitology 4: 239-251.

Paramonov, A.A (1964). Fundamentals of Phytonematology. II. Acad. Sci., USSR, Moscow, 444 pp.

Paramonov, A.A. (1967). A critical survey of the suborder Tylenchina (Filipjev, 1934) (Nematoda: Secernentea). In: Problems on evolution, morphology, taxonomy, and bio-chemistry of nematodes of plants. Acad. Sci. USSR, pp. 78-101.

Pearse, A.S. (1942). Introduction to Parasitology. Springfield, Illinois, USA, $375 \mathrm{pp}$.

Pedram, M. (2018). Nematodes of the family Longidoridae, pp. 627667. In: Ghaderi, R., Kashi, L. \& Karegar, A. (eds). Plant-parasitic nematodes in Iran. Shiraz, Iran, Marjaeelm \& Iranian Society of Nematology, $758 \mathrm{pp}$.

Pedram, M., N. Kanzaki, R.M. Giblin-Davis \& E. Pourjam (2018). A molecular phylogenetic approach for unravelling the taxonomic status of Basilaphelenchus persicus n. gen., n. sp. (Aphelenchoididae: Tylaphelenchinae). Nematology 20(6) 567-582. 
Peraza-Padilla, W., C. Cantalapiedra-Navarrete, T. Zamora-Araya, J.E. Palomares-Rius, P. Castillo \& A. Archidona-Yuste (2018). A new dagger nematode, Xiphinema tica n. sp. (Nematoda: Longidoridae), from Costa Rica with updating of the polytomous key of Loof and Luc (1990). European Journal of Plant Pathology 150(1): 73-90.

Pinochet, J. \& D.J. Raskl (1977). New records of nematodes from Korea, including Paratylenchus pandus n. sp. (Paratylenchidae: Nematoda). Journal of Nematology 9: 243-247.

Poghossian, H.E. (1966). A new nematode genus and species of the family Heteroderidae from the Armenian. Dan Reports of the Academy of Sciences of the Armenian SSR, 42: 117-123.

Poinar, G.O. (1969). Praecocilenchus rhaphidophorur n. gen., n. sp. (Nematoda: Aphelenchoidea) parasitizing Rhynchophorus bineatus (Montrouzier) Coleoptera: Curculionidae) in New Britain. Journal of Nematology 1: 227-231.

Potts, F.A. (1932). The phylum Nematoda, pp. 214-227. In: Borradaile, L.A., Potts, F.A. (eds.). The invertebrata. A manual for the use of students. Macmillan, New York.

Powers, T.O., J.G. Baldwin \& A.H. Bell, (1983). Taxonomic limits of the genus Nagelus (Thorne and Malek, 1968) Siddiqi, 1979 with a description of Nagelus borealis n. sp. from Alaska. Journal of Nematology 15: 582-593.

Qing X. \& W. Bert, (2018). 3D printing in zoological systematics: Integrative taxonomy of Labrys chinensis gen. nov., sp. nov. (Nematoda: Tylenchomorpha). Journal of Zoological Systematics and Evolutionary Research 56: 35-47.

Rashid, A., K. Singh, S.R. Misra \& T.N.A. Farooqi (1985). A ne species of Scutellonerna (Hoplolaiminae: Tylenchida) from Kerala, India. Indian Journal of Nematology 15: 127-128.

Rashid, F., E. Geraert \& R.D. Sharma (1987). Seven species of Tylenchida from Brazil with description of a new species (Nematoda: Tylenchoidea). Nematologia Mediterranea 15: 29-45.

Rashid, F., E. Geraert \& R.D. Sharma (1987). The genus Pehamigratus Sher, 1964 with description of two new species (Nematoda: Tylenchida). Revue de Nématology 10: 3-21.

Raski D.J. (1952). On the morphology of Criconemoides Taylor, 1936, with descriptions of six new species (Nematoda: Criconematidae) Proceedings of the Helminthological Society of Washington 19: 85-99.

Raski, D.J. (1957). Trophotylenchulus and Trophonema, two new genera of Tylenchulidae n. fam. (Nematoda). Nematologica 2: 8590.

Raski, D.J. (1975). Revision of the genus Paratylenchus Micoletzky, 1922, and descriptions of new species. Part II of three parts. Journal of Nematology 7: 274-295.

Raski, D.J. (1976). Revision of the genus Paratylenchus Micoletzky, 1922, and descriptions of new species. Part III of three parts Gracilacus. Journal of Nematology 8: 97-115.

Raski, D.J. (1991). Tylenchulidae in agricultural soils. In: Nickle, W. R. (Ed.). Manual of agricultural nematology. Marcel Dekker, Inc. Pp: 761-794.

Raski, D.J. \& E. Geraert (1986). Review of the genus Filenchus Andrássy, 1954 and descriptions of six new species (Nemata: Tylenchidae). Nematologica 32: 265-311.

Raski, D.J. \& A.M. Golden (1966). Studies on the genus Criconemoides Taylor, 1936 with descriptions of eleven new species and Bakernema variabile n. sp. (Criconematidae: Nematoda). Nematologica 11(1965): 501-565.

Raski, D.J. \& S.A. Sher (1952). Sphaeronema californicum, nov. gen. nov. spec. (Criconematidae: Sphaeronematinae, nov. subfam.) an endoparasite of the roots of certain plants. Proceedings of the Helminthological Society of Washington 19: 77-80.

Raski, D.J. \& I.A. Siddiqui (1975). Tylenchocriconema alleni n. g. n. sp. from Guatemala (Tylenchocriconematidae n. fam.; Tylenchocriconematoidea n. superfam: Nematoda). Journal of Nematology 7: 247-251.

Raski, D.J., P.K. Koshy \& V.K. Sosamma (1982). A revision of the subfamily Ecphyadophorinae Skarbilovich, 1959 (Tylenchidae: Nematoda). Revue de Nématologie 5: 119-138.
Raski, D.I. \& E. Geraert (1987). Review of the genus Filenchus Andrassy, 1954 and descriptions of six new species (Nemata: Tylenchidae). Nematologica 32(1986): 265-311.

Raski, D.I., A.R Maggenti, P.K. Koshy \& V.K. Sosamma (1980). Epicharinema keralense n.gen., n.sp., and comments on Atylenchinae and Ecphyadophorinae (Nemata: Tylenchidae). Revue de Nématologie 3: 297-304.

Ray, S. \& S.N. Das (1978). Hemicaloosia americana n. gen., n. sp. (Nematoda: Hemicycliophoridae from Orissa. India. OUAT Journal Research 8: 131-138.

Reay, F. (1991). A new genus and two new species of plant nematode (Tylenchidae) from Australia. Invertebrate Systematics 5(4): 855867.

Remillet, M. \& J.F. Silvain (1988). Noauidonema guyqnense n. g., n. sp. (Nematoda: Aphelenchoididae) ectoparasite of noctuids of the genus Spodoptera (Lepidoptera: Noctuidae). Revue de Nématology 11: 21-24.

Rey, J.M., M. Andres \& M. Arias (1988). A computer method for identifying nematode species. 1. Genus Longidorus (Nematoda: Longidoridae). Revue de Nématologie 11: 129-135.

Robbins, R.T., D.J.F. Brown, J.M. Halbrendt \& T.C. Vrain (1996). Compendium of juvenile stages of Xiphinema species (Nematoda: Longidoridae). Russian Journal of Nematology 4(2): 163-171.

Robinson, A.F., R.N. Inserra, E.P. Caswell-Chen, N. Vovlas \& A. Troccoli (1997). Rotylenchulus species: Identification, distribution, host ranges, and crop plant resistance. Nematropica 27(2): 127-180.

Rodriguez-M, R., S.A. Sher \& M.R. Siddiqi (1978). Systematics of the monodelphic species of Trichodoridae (Nematoda: Diphtherophorina) with descriptions of a new genus and four new species. Journal of nematology 10(2): 141-152.

Romanenko, N.D. (1978). A polytomic key for the identification of species of Longidorus Micoletzky, 1922. Fitogel'mintologicheskie issledovaniya 32: 111-114.

Rühm, W. (1956). Die Nematoden der Ipiden. Parasitologische Schriftenreihe 6: 1-437.

Ryss, A.Y. (1980). Pratylenchoides ivanovae sp. n. (Nematoda, Pratylenchidae) and key to species of the genus Pratylenchoides. Parazitologiya 14(6): 516-520.

Ryss, A.Y. (1988). Kornevye paraziticheskie nematody semeistva Pratylenchidae (Tylenchida) mirovoi fauny. [World fauna of the root parasitic nematodes of the family Pratylenchidae (Tylenchida)]. Nauka, Leningrad, $367 \mathrm{pp}$

Ryss, A.Y. (1997). Computerized identification of species of the genus Radopholus (Tylenchida: Pratylenchidae). Russian Journal of Nematology 5(2): 137-142.

Ryss, A.Y. (2002). Genus Pratylenchus Filipjev: multientry and monoentry keys and diagnostic relationships (Nematoda: Tylenchida: Pratylenchidae). Zoosystematica Rossica 10: 241-255.

Ryss, A.Y. (2003). Taxonomy, evolution and phylogeny of the genus Radopholus (didelphic species) according to morphological data, with a key to species (Nematoda: Tylenchida). Zoosystematica Rossica 11(2002): 243-256.

Ryss, A.Y. (2007). Taxonomy and evolution of the genus Pratylenchoides (Nematoda: Pratylenchidae). Parazitologyia 41: 161-194. [In Russian].

Ryss, A.Y. (2013). Textual, tabular and computer-aided keys to species of the genus Paraphelenchus Micoletzky, 1922 (Nematoda: Aphelenchidae). Parazitologiia 47: 45-55.

Sanwal, K.C. (1961). A key to the species of the nematode genus Aphelenchoides Fischer, 1894. Canadian Journal of Zoology 39: 143148.

Sauer, M.R. (1966). Morulaimus, a new genus of the Belonolaiminae. Nematologica 11: 609-618.

Schoemaker, R.W. (1967). Hemicycliophora nyanzae n. sp. found in East Africa with a key to the species of Hemicycliophora de Man, 1921. Nematologica 13(4): 541-546.

Schmidt, A. (1871). Über den Rübennematoden. Zeitschrift der Vereinte Rübenzuckerindustrie Zollverein 21: 1-19.

Scognamiglio, A., M. Talame' \& J.J. s'Jacob, (1970). Aprutides 
martuccii (Nematoda: Aphelenchoididae) n. g. - n. sp. Bollettino del Laboratorio di Entomologia Agraria 'Filippo Silvestri', Portici 28: 1-11.

Scopoli, G.A. (1777). Introductio ad historiam naturalem sistens genera lapidum, plantarum, et animalium hactenus detecta, caracteribus essentialibus donata, in tribus divusa, subinde ad leges naturae. Pragae, 506 pp.

Scotto, L., C. Massese \& G. Germani (2000). Description de quatre nouvelles especes et de quatre populations de Rotylenchus (Nematoda: Hoplolaimidae). Proposition d'une cle tabulaire. Nematology 2: 699-718.

Sen, D., A., Chatterjee \& B. Manna (2010). A new and a known species of Xiphinema Cobb, 1913 (Dorylaimida: Xiphinematidae) from West Bengal, India with a key to the mono-opisthodelphic species of the genus. Nematologia Mediterranea 38: 187-193.

Shahina, F. (1996). A diagnostic compendium of the genus Aphelenchoides Fischer, 1894 (Nematoda: Aphelenchida) with some new records of the group from Pakistan. Pakistan Journal of Nematology 14: 1-32.

Shahina, F. \& D.J. Hunt, (1995). A compendium of the genus Seinura Fuchs, 1931 (Nematoda: Aphelenchida). Afro-Asian Journal of Nematology 5: 169-177.

Shahina, F. \& M.A. Maqbool, (1990). Studies on the genus Neopsilenchus (Nematoda: Tylenchidae) with description of Acusilenchus n. subgenus, and three new species. Pakistan Journal of Nematology 8: 49-63.

Sharma, S.B. \& M.R. Siddiqi (1992). Bilobodera flexa gen $n, s p n$ (Nematoda, Heteroderidae) from Andhra Pradesh, India. Afro-Asian Journal of Nematology 2(1-2): 59-63.

Shaw, S.P., \& E. Khan (1992). Tylenchorhynchidae Golden, 1971 (Nematoda: Tylenchida) in India: 1. Amplimerlinius sikkimensis sp. n. from Sikkim with key to Amplimerlinius species and Tylenchorhynchus vanandi sp. $\mathrm{n}$. from Nagaland. Bulletin of Entomology, New Delhi 33: 7-13

Sher, S.A. (1963). Revision of the Hoplolaiminae (Nematoda). II. HoplolaimusDaday, 1905 and Aorolaimusn. gen. Nematologica 9(2) 267-295.

Sher, S.A. (1964). Revision of the Hoplolaiminae (Nematoda). III. Scutellonema Andrássy, 1958. Nematologica 9(1963): 421-443.

Sher, S.A. (1964). Revision of the Hoplolaiminae (Nematoda). IV. Peltamigratus n. gen.. Nematologica 9(3): 455-467.

Sher, S.A. (1965). Aphasmatylenchus nigeriensis n. gen. n. sp. (Aphasmatylenchinae n. subfam.: Tylenchoidea: Nematoda) from Nigerian soil. Proceeding of the Helminthological Society of Washington 32(2): 172-176.

Sher, S.A. (1965). Revised key to the Scutellonema Andrássy, 1958 (Hoplolaiminae: Nematoda). Nematologica 10: 648

Sher, S.A. (1966). Revision of the Hoplolaiminae (Nematoda) VI. Helicotylenchus Steiner, 1945. Nematologica 12: 1-56.

Sher, S.A. (1970). Revision of the genus Nacobbus Thome \& Allen, 1944 (Nematoda: Tylenchoidea). Journal of Nematology 2: 228-235.

Sher, S.A. (1973). Antarctylus humus n. gen. n. sp. from the subantarctic (Nematoda: Tylenchoidea). Journal of Nematology 5: 19-21.

Sher, S.A. (1974). The classification of Tetylenchus Filipjev, 1936 Leipotylenchus n. gen. (Leipotylenchinae n. subf.) and Triversus n. gen. (Nematoda: Tylenchoidea). Nematologica 19(3)(1973): 318325

Siddiqi, M.R. \& J.B. Goodey (1964). The status of the genera and subfamilies of the Criconematidae (Nematoda); with a comment on the position of Fergusobia. Nematologica 9(1963): 363-377.

Siddiqi, M.R. \& J.M. Lenné (1984). Pterotylenchus cecidogen/w n. gen., n. sp., a new stem-gall nematode parasitizing Desmodium ovaliforlium in Colombia. Journal of Nematology 16: 62-65.

Siddiqi, M.R. (1960). Telotylenchus, a new nematode genus from North India (Tylenchida: Telotylenchinae n. sub-fam). Nematologica 5: 73-77.

Siddiqi, M.R. (1961). Gymnotylenchus zeae, n. g., n. sp. (Nematoda: Neotylenchidae), a root associate of Zea mays L. (sweet corn) in Aligarh, North India. Nematologica 6: 59-63.
Siddiqi, M.R. (1963). On the classification of the Pratylenchidae (Thome, 1949) nov. grad. (Nematoda: Tylenchida), with a description of Zygotylenchus browni nov. gen. et nov.sp. Zeitschrijifiir Parasitenkunde 23: 390-396.

Siddiqi, M.R. (1970). On the plant-parasitic. nemmtode genera Merlinius gen. $n$. and Tylenchorhynchus Cobb and the classification of the families Dolichodoridae and Belonolalmldae n. rank. Proceeding of the Helminthological Society of Washington 37(1): 68-77.

Siddiqi, M.R. (1971). On the plant-parasitic nematode. genera Histotylenchus gen.n. and Telotylenchoides gen.n. (Telotylenchmae), wlth observations on the genus Paratrophurus Arias (Trophurinae). Nematologica 17: 190-200.

Siddiqi, M.R. (1971). Structure of the oesophagus in the classification of the superfamily Tylenchoidea (Nematoda). Indian Journal of Nematology 1: 25-43.

Siddiqi, M.R. (1972). On the genus Helicotylenchus Steiner, 1945 (Nematoda: Tylenchida), with descriptions of nine new species. Nematologica 18: 74-91.

Siddiqi, M.R. (1974). Systematics of the genus Trichodorus Cobb, 1913 (Nematoda: Dorylaimida), with descriptions of three new species. Nematologica 19: 259-278.

Siddiqi, M.R. (1976). New plant nematode genera Plesiodorus (Dolichodorinae), Meiodorus (Meiodorinae subfam. n.), Amplimerlinius (Merliniinae) and Gracilancea (Tylodoridae grad. n.). Nematologica 22: 390-416.

Siddiqi, M.R. (1978). The unusual position of the phasmids in Coslenchus costatus (de Man, 1921) gen.n., comb.n., and other Tylenchidae (Nematoda: Tylenchida). Nematologica 24: 449-455.

Siddiqi, M.R. (1979). Seven new species in a new nematode subfamily Duosulciinae (Tylenchidae), with proposals for Duosulcius gen.n., Zanenchus gen. n. and Neomalenchus gen.n. Nematologica 25: 215-236.

Siddiqi, M.R. (1980). Taxonomy of the plant nematode superfamily Hemicycliophoroidea, with a proposal for Criconematina, new suborder. Revue de Nématology 3: 179-199.

Siddiqi, M.R. (1980). Two new nematode genera, Safianema (Anguinidae) and Discotylenchus (Tylenchidae), with descriptions of three new species. Proceedings of the helminthological Society of Washington 47: 85-94.

Siddiqi, M.R. (1986). Tylenchida: parasites of plants and insects. Farnham Royal, London: Commonwealth Agricultural Bureaux, 645 pp.

Siddiqi, M.R. (1991). Tanzanius coffeae gen.n., sp.n. and Zygradus rector gen.n., sp.n. (Nematoda: Tylenchina) from Africa. Afro-A sian journal of Nematology 1: 101-107.

Siddiqi, M.R. (1994). Nematodes of tropical rainforests. 3. Three new genera and five new species of Tylenchs. Afro-Asian Journal of Nematology 4(1): 22-31.

Siddiqi, M.R. (2000). Tylenchida: parasites of plants and insects. CABI Publishing, Wallingford, UK, $833 \mathrm{pp}$.

Siddiqi, M.R. (2002). Ecuadorus equatorius gen. n., sp. n. and Nanidorus mexicanus sp. n. (Nematoda: Trichodoridae). International Journal of Nematology 12(2): 197-202.

Siddiqi, M.R., \& D. Sturhan (2014). A remarkable new nematode genus Telomerlinius gen. $\mathrm{n}$. (Tylenchida: Merliniidae), with descriptions of two new species. International Journal of Nematology 24(1): 40-48.

Siddiqi, M.R., D.J. Hooper \& E. Khan (1963). A new nematode genus Paralongidorus (Nematoda: Dorylaimoidea) with descriptions of two new species and observations on Paralongidorus citri (Siddiqi 1959) n. comb. Nematologica 9(1): 7-14.

Sinha, B., A. Choudhury \& Q.H. Baqri (1985). Studies on the nematodes from mangrove swamps of deltaic Sundarbans, West Benghal. I. Indoditylenchus sundarbanensis n. gen., n. sp. (Tylenchidae: Tylenchida). Indian Journal of Helminthology 2: 31-35.

Sivakumar, C.V. \& E. Khan (1982). Description of Hirschmanniella kaverii sp. n. (Radopholidae: Nematoda) with a key for identification of Hirschmanniella spp. Indian Journal of Nematology 12: 86-90.

S'Jacob, J.J. (1960). Hoplotylus femina n.g., n.sp. (Pratylenchinae: 
Tylenchida) associated with ornamental trees. Nematologica 4 1959): 317-321.

Skarbilovich, T.S. (1947). Revision of the systematics of the nematode family Anguillulinidae Baylis and Daubney,1926. Doklady Akademii Nauk, SSR 57: 307-308.

Skarbilovich, T.S. (1959). On the structure and systematics of nematode order Tylenchida Thome, 1949. Acta Parasitologica Polonica 7: 117-132.

Skwiercz, A.T. (1984). Two new species of the genus Scutylenchus Jairajpuri, 1971 (Tylenchoidea: Nematoda) from Poland with a key to the species. Revue de Nématologie 7(1): 87-93.

Slobodyanyuk, O.V. (1991). Validation of the genus Rubzovinema gen $\mathrm{n}$.(Sphaerularioidea) and revision of Rubzovinema ceratophylla comb. n. Zoologičeskij žurnal 70(9): 33-43.

Slobodyanyuk, O.V. (1999). Revision of the species Psyllotylenchus pawlowskyi (Kurochkin, 1960) Poinar and Nelson, 1973. II. Description of Kurochkinitylenchus laevicepsi gen. n., sp. n. and Spilotylenchidae fam. n. Russian Journal of Nematology 7: 1-18

Smart, G.C. \& K.B. Nguyen, (1991). Sting and awl nematodes: Belonolaimus spp and Dolichodorus spp., pp. 627-667. In: W.R. Nickle (ed). Manual of Agricultural Nematology. Marcel Dekker, New York. 1052 pp.

Smart, G.C., JR. \& N.B. Khuong (1985). Dolichodorus miradvulvus (Nematoda: Tylenchida) with a key to the species. Journal of Nematology 17(1): 29-37.

Solov'eva, G.I. (1975). Parasitic Nematodes of Woody and Herbaceous Plants: A Review of the Genus Paratylenchus Micoletzky, 1922 (Nematoda: Criconematidae) (Paraziticheskie Nematody Drevesnykh i Travyanistykh Rastenii: Obzor Roda Paratylenchus Micoletzky, 1922 (Nematoda: Criconematidae)) (Vol. 73, No. 52020). Agriculture Research Service, United States Department of Agriculture and the National Science Foundation, Washington, DC, 134 pp.

Soni, G.R., \& H.S. Nama (1981). Tobrilus kherai sp. n.(Nematoda: Tripylidae) with a key to the species of longus group. Indian Journal of Nematology 11(2): 141-146.

Southern, R. (1914). Clare Island Survey. Part 54. Nemathelmia, Kinorhyncha, and Chaetognatha. Proceedings Royal Ireland Academy 31: 1-80.

Spaull, V.W. (1972). Antarctenchus hooperi n.gen., n.sp. (Nematoda: Dolichodoridae) from Signy Island, South Orkney Islands, with the erection of a new subfamily. Nematologica 18: 353-359.

Steiner, G. (1945). Helicorylenchus, a new genus of plant-parasitic nematodes and its relationship to Rotylenchus Filipjev. Proceedings of the Helminthological Society of Washington 12: 34-38.

Steiner, G. (1949). Plant nematodes the grower should know. Proceedings of Soil Science Society of Florida 4-B: 72-117.

Sturhan, D. (2002). Notes on the genus Cactodera Krall \& Krall, 1978 and proposal of Betulodera betulae gen. nov., comb. nov. (Nematoda: Heteroderidae). Nematology 4(7): 875-882.

Sturhan, D. (2012). Contribution to a revision of the family Merliniidae Ryss, 1998, with proposal of Pratylenchoidinae subfam. n., Paramerlinius gen. n., Macrotylenchus gen. $n$. and description of $M$. hylophilus sp. n.(Tylenchida). Journal of Nematode Morphology and Systematics 15(2): 127-147.

Sturhan, D. \& M.W. Brzeski (1991). Stem and bulb nematodes, Ditylenchus spp., pp: 423-464 In: Nickle, W. R. (ed). Manual of agricultural nematology. Marcel Dekker, Inc., 1052 pp.

Subbotin, S., W. Wouts \& D. Sturhan (2007). An unusual cyst nematode from New Zealand, Paradolichodera tenuissima gen. n., sp. n. (Tylenchida: Heteroderidae). Nematology 9(4): 561-571.

Subbotin, S.A. \& J. Franco (2012). Cyst nematodes. pp. 299-357. In: Manzanilla-López R.H., and Marbán-Mendoza N. (eds). Practica Plant Nematology. Colegio de Postgraduados, México. Biblioteca básica de Agricultura. México. 883 pp.

Subbotin, S.A. \& I.T. Riley, (2012). Stem and gall forming nematodes. Pp. 521-578. In: Manzanilla-López R.H., and Marbán-Mendoza N. (eds). Practical Plant Nematology. Colegio de Postgraduados, México. Biblioteca básica de Agricultura. México. 883 p.

Subbotin, S.A., M. Mundo-Ocampo \& J. Baldwin (2010). Systematics of cyst nematodes (Nematoda: Heteroderinae). Nematology monographs \& perspectives Vol. 8A. Brill, Boston, MA., 300 pp.

Subbotin, S.A., M. Mundo-Ocampo \& J. Baldwin (2010). Systematics of cyst nematodes (Nematoda: Heteroderinae). Nematology monographs \& perspectives Vol. 8B. Brill, Boston, MA., 512 pp.

Sultan, M.S. \& M.S. Jairalpuri (1982). Two new species of the genus Cephalenchus (Goodey, 1962) Golden, 1971 with a key to the species. Indian Journal of Nematology 11(1981): 165-171.

Sultan, M.S., I. Singh \& P.K. Sakhula (1988). Plant parasitic nematodes of Punjab. II. Neopsilenchus longicaudatus n. sp. (Nematoda: Tylenchidae). Indian Journal of Nematology 17(1987): 330-332.

Sumenkova, N.I. (1984). Review of generic and subgeneric categories of nematodes in the family Tylenchidae Örley, 1880, pp: 132-144. In: E.S. Tyrlygina (ed). Taxonomy and Biology of Plant Nematodes. Moscow, USSR 'Nauka'.

Sumenkova, N.I. (1989). Nematodes of plants and soils: Neotylenchoidea. Brill, 121 pp.

Szczygiel, A. (1969). A new genus and four new species of the subfamily Tylenchinae de Man, 1876 (Nematoda: Tylenchidae) from Poland. Opuscula zoological Budapestensis 9: 159-170.

Talavera, M. \& A. Tobar (1996). Description of Pratylenchoides nevadensis sp. $\mathrm{n}$. from Southern Spain (Tylenchida: Pratylenchidae). Afro-Asian Journal of Nematology 6(1): 46-49.

Tanha Maafi, Z., M. Amani, J.D. Stanley, R.N. Inserra, E. Van den Berg \& S.A. Subbotin (2012). Description of Tylenchulus musicola sp. n. (Nematoda: Tylenchulidae) from banana in Iran with molecular phylogeny and characterisation of species of Tylenchulus Cobb, 1913. Nematology 14(3): 353-369.

Tanha Maafi, Z., D. Sturhan, A. Kheiri \& E. Geraert (2007). Species of the Heterodera avenae group (Nematoda: Heteroderidae) from Iran. Russian Journal of Nematology 15(1): 49-58.

Tarjan, A.C. (1958). A new genus, Pseudhalenchus (Tylenchinae: Nematoda), with descriptions of two new species. Proceedings of the Helminthological Society of Washington 25: 20-25.

Tarjan, A.C. (1964). A compendium of the genus Tylenchorhynchus (Tylenchidae, Nematoda). Proceedings of the Helminthological Society of Washington 31: 270-280.

Tarjan, A.C. (1966). A compendium of the genus Criconemoides (Criconematidae: Nemata). Proceedings of the Helminthological Society of Washington 33: 109-119.

Tarjan, A.C. (1973). A synopsis of the genera and species in the Tylenchorhynchinae (Tylenchoidea, Nematoda). Proceedings of the Helminthological Society of Washington 40: 123-144.

Tarjan, A.C. \& A. Aragon (1982). An analysis of the genus Bursaphelenchus Fuchs, 1937. Nematropica 12: 121-144.

Taylor, A.L. \& J.N. Sasser (1978). Biology, identification and control of root-knot nematodes (Meloidogyne species). Department of Plant Pathology, North Carolina State University, United States Agency for International Development, $111 \mathrm{pp}$.

Taylor, A.L. (1936). The genera and species of the Criconematinae, a sub-family of the Anguillulinidae (Nematoda). Transactions of the American Microscopical Society 55: 391-421.

Taylor, C.E. \& D.J.F. Brown (1997). Nematode vectors of plant viruses: CAB International, Wallingford, UK, 286 pp.

Thorne, G. (1935). Notes on free-living and plant-parasitic nematodes, 1. Proceedings of the Helminthological Society of Washington 2: 46-47.

Thorne, G. (1941). Some nematodes of the family Tylenchidae, which do not possess a valvular median oesophageal bulb. Great Basin Naturalist 2: 37-85.

Thorne, G. (1943). Cacopaurus pestis, nov. gen., nov. spec. (Nematoda: Criconematinae), a destructive parasite of the walnut Juglans regia Linn. Proceedings of the Helminthological Society of Washington 10: 78-83.

Thorne, G. (1949). On the classification of the Tylenchida, new order (Nematoda, Phasmidia). Proceedings of the Helminthological Society of Washington 16(2): 37-73.

Thorne, G. \& M.W. Allen (1944). Nacobbus dorsalis nov. gen., nov. spec. (Nematoda: Tylenchidae) producing galls in the roots of alfileria, 
Erodium cicutarium (L) L'Her. Proceedings of the helminthological Society of Washington 11: 27-31.

Thorne, G. \& R.B. Malek (1968). Nematodes of the Northern Great Plains. Part 1. Tylenchida (Nemata: Secernentea). South Dakota Agricultural Experiment Station Technical Bulletin 31, 111 pp

Trinh, P.Q., L. Waeyenberge, C.N. Nguyen, J.G. Baldwin, G. Karssen \& M. Moens (2009). Apratylenchus vietnamensis gen. n., sp.n. and $A$. binhigen. n., sp. n. sedentary Pratylenchidae (Nematoda: Tylenchida) from coffee in Vietnam, with proposal of Apratylenchinae subfam. n. Nematology 11(4): 565-581.

Uzma, I., K. Nasira, K. Firoza \& F. Shahina (2015). Review of the genus Helicotylenchus Steiner, 1945 (Nematoda: Hoplolaimidae) with updated diagnostic compendium. Pakistan Journal of Nematology 33: $115-160$

van den Berg, E. (1987). More Hemicycliophora species from South Africa (Hemicycliophoridae: Nematoda). Phytophylactica 19(3): 309-314.

van den Berg, E. \& Heyns, J. (1973). South African Hoplolaiminae 2. The genus Scutellonema Andrássy, 1958. Phytophylactica 5: 23-40.

van den Berg, E. \& P. Quinéhérve, (1995). Ogma toparti sp. n. and two known Criconematoidea from the French Caribbean (Nemata: Tylenchina). Fundamental and Applied Nematology 18: 361-369.

Vinciguerra, M.T. (2006). Dorylaimida. Part II: Superfamily Dorylaimoidea. Freshwater nematodes: Ecology and taxonomy. CABI Publishing, Wallingford, UK, 392-467.

Viscardi, T. \& M.W. Brzeski (1993). DITYL: computerized key for species identification of Ditylenchus (Nematoda: Anguinidae). Fundamental and Applied nematology 16(5): 389-392.

von Daday, (1905). Untersuchungen über die Süsswasser-Mikrofauna Paraguays. Zoologica, Stuttgart 18: 1-349.

Vovlas, N., A. Troccoli \& P. Castillo (2000). Hemicriconemoides macrodorus $\mathrm{n}$. sp. with observations on two other species of the genus (Nematoda: Criconematidae). Nematology 2: 395-405.

Wachek, F. (1955). Die entoparasitischen Tylenchiden. Parasitolog Schriftenreihe, Heft. 3, VEB. G. Fischer Verlag. Jena., 119 pp.

Whitehead, A.G. (1958). Rorylenchoides brevis n. g., n. sp (Rotylenchoidinae n. subfam: Tylenchida). Nematologica 3: 327331.

Whitehead, A.G. (1960). Trichotylenchus falciformis n. g., n. sp. (Belonolaiminae n. subfam.: Tylenchida Thorne, 1949) an associate of grassroots (Hypanhenia sp.) in Southern Tanganyika. Nematologica 4: $279-285$.

Wouts, W.M. (1966). The identity of New Zealand populations of Tylenchorhynchus capitatus Allen, 1955, with a description of an intersex. New Zealand Journal of Science 9: 878-881.

Wouts, W.M. (1978). Campbellenchinae (Nematoda: Tylodoridae), a new subfamily from Campbell Island, with a description of two new species. New Zealand journal of Zoology 4 (1977): 213-216.

Wouts, W.M. (1984). Globodera zelandica n. sp. (Nematoda: Heteroderidae) from New Zealand, with a key to the species of Globodera. New Zealand Journal of Zoology 11(2): 129-135.

Wouts, W.M. (2006). Criconematina (Nematoda: Tylenchida). Fauna of New Zealand 55: 1-228.

Wouts, W.M. \& J.G. Baldwin, (1998). Taxonomy and identification. Pp: 83-122. In: Sharma, S.B. (ed). The cyst nematodes. Springer, Dordrecht, $452 \mathrm{pp}$.

Wouts, W.M. \& S.A. Sher, (1971). The genera of the subfamily Heteroderinae (Nematoda Tylenchoidea) with a description of two new genera. Journal of Nematology 3: 129-144.

Wouts, W.M., \& G.W. Yeates (1994). Helicotylenchus species (Nematoda: Tylenchida) from native vegetation and undisturbed soils in New Zealand. New Zealand Journal of Zoology 21(2): 213224.

Wu, L.Y. (1964). Bakernema n. gen. (Criconematidae: Nematoda). Canadian Journal of Zoology 42, 921.

Xu, C., H. Xie, C. Zhao, S. Zhang \& X. Su (2012). Review of the genus Scutylenchus Jairajpuri, 1971 (Nematoda: Tylenchida), with description of Scutylenchus dongtingensis $\mathrm{n}$. sp. from rhizosphere soil of grass in China. Zootaxa 3437: 32-42.

Xu, Y., W. Ye, J. Wang \& Z. Zhao, (2018). Morphological and molecular characterisation of Longidorus pinus sp. $\mathrm{n}$. (Nematoda: Longidoridae) from China and a key to known species of Longidorus in China. Nematology 20(7): 617-639.

Yaghoubi, A. E. Pourjam \& M. Pedram (2018). Description of a new species of the genus Anguillonema Fuchs, 1938 (Nematoda: Sphaerularioidea) with an identification key to the species. Journal of Helminthology 93: 504-512.

Yaghoubi, A., E. Pourjam, S. Alvarez-Ortega, G. Liebanas, M.R. Atighi \& M. Pedram (2016). Discopersicus n. gen., a new member of the family Tylenchidae Örley, 1880 with detailed SEM study on two known species of the genus Discotylenchus Siddiqi, 1980 (Nematoda; Tylenchidae) from Iran. Journal of Nematology 48(3): 214-221.

Yaghoubi, A., E. Pourjam, M. Pedram M.R. Siddiqi \& M.R. Atighi (2014). Molecular and morphological characterization of Abursanema iranicum n. gen., n. sp. (Nematoda: Hexatylina, Sphaerularioidea) from Iran. Zootaxa 3826(2): 301-314.

Ye, W. \& R.T. Robbins (2004). Cluster analysis of Longidorus species (Nematoda: Longidoridae), a new approach in species identification. Journal of Nematology 36: 207-219.

Yeates G.W., P.A.A Loof \& W.M. Wouts (1997). Criconematidae (Nematoda: Tylenchida) from the New Zealand region: analysis of and a key to Criconema (Nothocriconemella) species. New Zealand Journal of Zoology 24: 153-162.

Yin, K., Y. Fang \& A.C. Tarjan (1988). A key to species in the genus Bursaphelenchus with a description of Bursaphelechus hunanensis sp. n. (Nematoda: Aphelenchoididae) found in pinewood in Hunan Province, China. Proceedings of the Helminthological Society of Washington 55: 1-11.

Zahedi, E., G. Niknam, W. Decraemer \& A. Karegar (2009). Trichodorus arasbaranensis n. sp. (Nematoda: Trichodoridae) from a natural forest in Arasbaran, north-west Iran. Nematology 11: 243-252.

Zeng, Y., W. Ye, S. Lane M. Tredway \& M. Martin (2012). Description of Hemicaloosia graminis n. sp.(Nematoda: Caloosiidae) associated with turfgrasses in North and South Carolina, USA. Journal of Nematology 44(2): 134-141.

Zhou, K., H.H. Wang, W. Ye, D.L. Peng \& J.L. Liao (2014). Cryphodera sinensis n. sp. (Nematoda: Heteroderidae), a non-cyst-forming parasitic nematode from the root of ramie Boehmeria nivea in China. Journal of Helmintology 88: 468-480.

Zhao, Z.Q., W. Ho, R. Griffin, M. Surrey, R. Taylor, L.T. Aalders, N.L. Bell, Y.M. Xu. \& B.J.R. Alexander (2017). First record of the root knot nematode, Meloidogyne minor in New Zealand with description, sequencing information and key to known species of Meloidogyne in New Zealand. Zootaxa 4231(2): 203-220.

Zheng, J., R. Robbins, D. Peng \& D. Brown (2001). Description of Longidorus hangzhouensis sp. n. (Nemata: Longidoridae) from Zhejiang province, new geographical records of $L$. henanus $\mathrm{Xu}$ \& Cheng, 1992, and an identification key for Longidorus species occurring in China. Nematology 3(3): 219-227.

Zullini, A. \& G. Manganelli (1989). A new computer program for nematode identification. Bioinformatics 5(3): 243-244. 

Dr. Albert G. Orr, Griffith University, Nathan, Australia

Dr. Sameer Padhye, Katholieke Universiteit Leuven, Belgium

Dr. Nancy van der Poorten, Toronto, Canada

Dr. Kareen Schnabel, NIWA, Wellington, New Zealand

Dr. R.M. Sharma, (Retd.) Scientist, Zoological Survey of India, Pune, India

Dr. Manju Siliwal, WILD, Coimbatore, Tamil Nadu, India

Dr. G.P. Sinha, Botanical Survey of India, Allahabad, India

Dr. K.A. Subramanian, Zoological Survey of India, New Alipore, Kolkata, India

Dr. P.M. Sureshan, Zoological Survey of India, Kozhikode, Kerala, India

Dr. R. Varatharajan, Manipur University, Imphal, Manipur, India

Dr. Eduard Vives, Museu de Ciències Naturals de Barcelona, Terrassa, Spain

Dr. James Young, Hong Kong Lepidopterists' Society, Hong Kong

Dr. R. Sundararaj, Institute of Wood Science \& Technology, Bengaluru, India

Dr. M. Nithyanandan, Environmental Department, La Ala Al Kuwait Real Estate. Co. K.S.C., Kuwait

Dr. Himender Bharti, Punjabi University, Punjab, India

Mr. Purnendu Roy, London, UK

Dr. Saito Motoki, The Butterfly Society of Japan, Tokyo, Japan

Dr. Sanjay Sondhi, TITLI TRUST, Kalpavriksh, Dehradun, India

Dr. Nguyen Thi Phuong Lien, Vietnam Academy of Science and Technology, Hanoi, Vietnam

Dr. Nitin Kulkarni, Tropical Research Institute, Jabalpur, India

Dr. Robin Wen Jiang Ngiam, National Parks Board, Singapore

Dr. Lional Monod, Natural History Museum of Geneva, Genève, Switzerland.

Dr. Asheesh Shivam, Nehru Gram Bharti University, Allahabad, India

Dr. Rosana Moreira da Rocha, Universidade Federal do Paraná, Curitiba, Brasil

Dr. Kurt R. Arnold, North Dakota State University, Saxony, Germany

Dr. James M. Carpenter, American Museum of Natural History, New York, USA

Dr. David M. Claborn, Missouri State University, Springfield, USA

Dr. Kareen Schnabel, Marine Biologist, Wellington, New Zealand

Dr. Amazonas Chagas Júnior, Universidade Federal de Mato Grosso, Cuiabá, Brasil

Mr. Monsoon Jyoti Gogoi, Assam University, Silchar, Assam, India

Dr. Heo Chong Chin, Universiti Teknologi MARA (UiTM), Selangor, Malaysia

Dr. R.J. Shiel, University of Adelaide, SA 5005, Australia

Dr. Siddharth Kulkarni, The George Washington University, Washington, USA

Dr. Priyadarsanan Dharma Rajan, ATREE, Bengaluru, India

Dr. Phil Alderslade, CSIRO Marine And Atmospheric Research, Hobart, Australia

Dr. John E.N. Veron, Coral Reef Research, Townsville, Australia

Dr. Daniel Whitmore, State Museum of Natural History Stuttgart, Rosenstein, Germany.

Dr. Yu-Feng Hsu, National Taiwan Normal University, Taipei City, Taiwan

Dr. Keith V. Wolfe, Antioch, California, USA

Dr. Siddharth Kulkarni, The Hormiga Lab, The George Washington University, Washington,

D.C., USA

Dr. Tomas Ditrich, Faculty of Education, University of South Bohemia in Ceske

Budejovice, Czech Republic

Dr. Mihaly Foldvari, Natural History Museum, University of Oslo, Norway

Dr. V.P. Uniyal, Wildlife Institute of India, Dehradun, Uttarakhand 248001, India

Dr. John T.D. Caleb, Zoological Survey of India, Kolkata, West Bengal, India

Dr. Priyadarsanan Dharma Rajan, Ashoka Trust for Research in Ecology and the Environment (ATREE), Royal Enclave, Bangalore, Karnataka, India

\section{Fishes}

Dr. Neelesh Dahanukar, IISER, Pune, Maharashtra, India

Dr. Topiltzin Contreras MacBeath, Universidad Autónoma del estado de Morelos, México

Dr. Heok Hee Ng, National University of Singapore, Science Drive, Singapore

Dr. Rajeev Raghavan, St. Albert's College, Kochi, Kerala, India

Dr. Robert D. Sluka, Chiltern Gateway Project, A Rocha UK, Southall, Middlesex, UK

Dr. E. Vivekanandan, Central Marine Fisheries Research Institute, Chennai, India

Dr. Davor Zanella, University of Zagreb, Zagreb, Croatia

Dr. A. Biju Kumar, University of Kerala, Thiruvananthapuram, Kerala, India

Dr. Akhilesh K.V., ICAR-Central Marine Fisheries Research Institute, Mumbai Research

Centre, Mumbai, Maharashtra, India

Dr. J.A. Johnson, Wildlife Institute of India, Dehradun, Uttarakhand, India

\section{Amphibians}

Dr. Sushil K. Dutta, Indian Institute of Science, Bengaluru, Karnataka, India

Dr. Annemarie Ohler, Muséum national d'Histoire naturelle, Paris, France

\section{Reptiles}

Dr. Gernot Vogel, Heidelberg, Germany

Dr. Raju Vyas, Vadodara, Gujarat, India

Dr. Pritpal S. Soorae, Environment Agency, Abu Dubai, UAE.

Prof. Dr. Wayne J. Fuller, Near East University, Mersin, Turkey

Prof. Chandrashekher U. Rivonker, Goa University, Taleigao Plateau, Goa. India

Dr. S.R. Ganesh, Chennai Snake Park, Chennai, Tamil Nadu, India

Dr. Himansu Sekhar Das, Terrestrial \& Marine Biodiversity, Abu Dhabi, UAE
Birds

Dr. Hem Sagar Baral, Charles Sturt University, NSW Australia

Dr. Chris Bowden, Royal Society for the Protection of Birds, Sandy, UK

Dr. Priya Davidar, Pondicherry University, Kalapet, Puducherry, India

Dr. J.W. Duckworth, IUCN SSC, Bath, UK

Dr. Rajah Jayapal, SACON, Coimbatore, Tamil Nadu, India

Dr. Rajiv S. Kalsi, M.L.N. College, Yamuna Nagar, Haryana, India

Dr. V. Santharam, Rishi Valley Education Centre, Chittoor Dt., Andhra Pradesh, India

Dr. S. Balachandran, Bombay Natural History Society, Mumbai, India

Mr. J. Praveen, Bengaluru, India

Dr. C. Srinivasulu, Osmania University, Hyderabad, India

Dr. K.S. Gopi Sundar, International Crane Foundation, Baraboo, USA

Dr. Gombobaatar Sundev, Professor of Ornithology, Ulaanbaatar, Mongolia

Prof. Reuven Yosef, International Birding \& Research Centre, Eilat, Israel

Dr. Taej Mundkur, Wetlands International, Wageningen, The Netherlands

Dr. Carol Inskipp, Bishop Auckland Co., Durham, UK

Dr. Tim Inskipp, Bishop Auckland Co, Durham, UK

Dr. V. Gokula, National College, Tiruchirappalli, Tamil Nadu, India

Dr. Arkady Lelej, Russian Academy of Sciences, Vladivostok, Russia

Dr. Simon Dowell, Science Director, Chester Zoo, UK

Dr. Mário Gabriel Santiago dos Santos, Universidade de Trás-os-Montes e Alto Douro,

Quinta de Prados, Vila Real, Portugal

Dr. Grant Connette, Smithsonian Institution, Royal, VA, USA

Dr. M. Zafar-ul Islam, Prince Saud Al Faisal Wildlife Research Center, Taif, Saudi Arabia

Mammals

Dr. Giovanni Amori, CNR - Institute of Ecosystem Studies, Rome, Italy

Dr. Anwaruddin Chowdhury, Guwahati, India

Dr. David Mallon, Zoological Society of London, UK

Dr. Shomita Mukherjee, SACON, Coimbatore, Tamil Nadu, India

Dr. Angie Appel, Wild Cat Network, Germany

Dr. P.O. Nameer, Kerala Agricultural University, Thrissur, Kerala, India

Dr. Ian Redmond, UNEP Convention on Migratory Species, Lansdown, UK

Dr. Heidi S. Riddle, Riddle's Elephant and Wildlife Sanctuary, Arkansas, USA

Dr. Karin Schwartz, George Mason University, Fairfax, Virginia.

Dr. Lala A.K. Singh, Bhubaneswar, Orissa, India

Dr. Mewa Singh, Mysore University, Mysore, India

Dr. Paul Racey, University of Exeter, Devon, UK

Dr. Honnavalli N. Kumara, SACON, Anaikatty P.O., Coimbatore, Tamil Nadu, India

Dr. Nishith Dharaiya, HNG University, Patan, Gujarat, India

Dr. Spartaco Gippoliti, Socio Onorario Società Italiana per la Storia della Fauna "Giuseppe

Altobello", Rome, Italy

Dr. Justus Joshua, Green Future Foundation, Tiruchirapalli, Tamil Nadu, India

Dr. H. Raghuram, The American College, Madurai, Tamil Nadu, India

Dr. Paul Bates, Harison Institute, Kent, UK

Dr. Jim Sanderson, Small Wild Cat Conservation Foundation, Hartford, USA

Dr. Dan Challender, University of Kent, Canterbury, UK

Dr. David Mallon, Manchester Metropolitan University, Derbyshire, UK

Dr. Brian L. Cypher, California State University-Stanislaus, Bakersfield, CA

Dr. S.S. Talmale, Zoological Survey of India, Pune, Maharashtra, India

Prof. Karan Bahadur Shah, Budhanilakantha Municipality, Kathmandu, Nepal

Dr. Susan Cheyne, Borneo Nature Foundation International, Palangkaraja, Indonesia

Dr. Hemanta Kafley, Wildlife Sciences, Tarleton State University, Texas, USA

\section{Other Disciplines}

Dr. Aniruddha Belsare, Columbia MO 65203, USA (Veterinary)

Dr. Mandar S. Paingankar, University of Pune, Pune, Maharashtra, India (Molecular)

Dr. Jack Tordoff, Critical Ecosystem Partnership Fund, Arlington, USA (Communities)

Dr. Ulrike Streicher, University of Oregon, Eugene, USA (Veterinary)

Dr. Hari Balasubramanian, EcoAdvisors, Nova Scotia, Canada (Communities)

Dr. Rayanna Hellem Santos Bezerra, Universidade Federal de Sergipe, São Cristóvão, Brazil

Dr. Jamie R. Wood, Landcare Research, Canterbury, New Zealand

Dr. Wendy Collinson-Jonker, Endangered Wildlife Trust, Gauteng, South Africa

Dr. Rajeshkumar G. Jani, Anand Agricultural University, Anand, Gujarat, India

Dr. O.N. Tiwari, Senior Scientist, ICAR-Indian Agricultural Research Institute (IARI), New

Delhi, India

Dr. L.D. Singla, Guru Angad Dev Veterinary and Animal Sciences University, Ludhiana, India

Dr. Rupika S. Rajakaruna, University of Peradeniya, Peradeniya, Sri Lanka

Dr. Bahar Baviskar, Wild-CER, Nagpur, Maharashtra 440013, India

Reviewers 2018-2020

Due to pausity of space, the list of reviewers for 2018-2020 is available online.
The opinions expressed by the authors do not reflect the views of the Journal of Threatened Taxa, Wildlife Information Liaison Development Society, Zoo Outreach Organization, or any of the partners. The journal, the publisher, the host, and the partners are not responsible for the accuracy of the political boundaries shown in the maps by the authors.

\footnotetext{
Print copies of the Journal are available at cost. Write to:

The Managing Editor, JoTT,

c/o Wildlife Information Liaison Development Society,

No. 12, Thiruvannamalai Nagar, Saravanampatti - Kalapatti Road,

Saravanampatti, Coimbatore, Tamil Nadu 641035, India

ravi@threatenedtaxa.org
} 




www.threatenedtaxa.org

The Journal of Threatened Taxa (JoTT) is dedicated to building evidence for conservation globally by publishing peer-reviewed articles online every month at a reasonably rapid rate at www.threatenedtaxa.org. All articles published in JoTT are registered under Creative Commons Attribution 4.0 International License unless otherwise mentioned. JoTT allows allows unrestricted use, reproduction, and distribution of articles in any medium by providing adequate credit to the author(s) and the source of publication.

\section{ISSN $0974-7907$ (Online) | ISSN $0974-7893$ (Print)}

\section{September 2021 | Vol. 13 | No. 11 | Pages: 19431-19674 Date of Publication: 26 September 2021 (Online \& Print) DOI: 10.11609/jott.2021.13.11.19431-19674}

Articles

Understanding human-flying fox interactions in the Agusan Marsh Wildlife Sanctuary as basis for conservation policy interventions

- Sherryl L. Paz \& Juan Carlos T. Gonzalez, Pp. 19431-19447

Argentinian odonates (dragonflies and damselflies): current and future distribution and discussion of their conservation

- A. Nava-Bolaños, D.E. Vrech, A.V. Peretti \& A. Córdoba-Aguilar, Pp. 19448-19465

\section{Communications}

The diel activity pattern of small carnivores of Western Ghats, India: a case study at Nelliampathies in Kerala, India

- Devika Sanghamithra \& P.O. Nameer, Pp. 19466-19474

Distribution and threats to Smooth-Coated Otters Lutrogale perspicillata (Mammalia: Carnivora: Mustelidae) in Shuklaphanta National Park, Nepal

- Gopi Krishna Joshi, Rajeev Joshi \& Bishow Poudel, Pp. 19475-19483

Wildlife hunting practices of the Santal and Oraon communities in Rajshahi, Bangladesh - Azizul Islam Barkat, Fahmida Tasnim Liza, Sumaiya Akter, Ashikur Rahman Shome \& M. Fazle Rabbe, Pp. 19484-19491

Ethnozoological use of primates in northeastern India

- Deborah Daolagupu, Nazimur Rahman Talukdar \& Parthankar Choudhury, Pp. 19492-19499

Factors influencing the flush response and flight initiation distance of three owl species in the Andaman Islands

- Shanmugavel Sureshmarimuthu, Santhanakrishnan Babu, Honnavalli Nagaraj Kumara \& Nagaraj Rajeshkumar, Pp. 19500-19508

Birds of Barandabhar Corridor Forest, Chitwan, Nepal

- Saneer Lamichhane, Babu Ram Lamichhane, Kapil Pokharel, Pramod Raj Regmi, Tulasi Prasad Dahal, Santosh Bhattarai, Chiranjibi Prasad Pokheral, Pabitra Gotame,

Trishna Rayamajhi, Ram Chandra Kandel \& Aashish Gurung, Pp. 19509-19526

On some additions to the amphibians of Gunung Inas Forest Reserve, Kedah,

Peninsular Malaysia

- Shahriza Shahrudin, Pp. 19527-19539

Reviews

A review of research on the distribution, ecology, behaviour, and conservation of the Slender Loris Loris lydekkerianus (Mammalia: Primates: Lorisidae) in India

- Mewa Singh, Mridula Singh, Honnavalli N. Kumara, Shanthala Kumar, Smitha D. Gnanaolivu \& Ramamoorthy Sasi, Pp. 19540-19552

Bivalves (Mollusca: Bivalvia) in Malaysian Borneo: status and threats

- Abdulla-Al-Asif, Hadi Hamli, Abu Hena Mustafa Kamal, Mohd Hanafi Idris, Geoffery James Gerusu, Johan Ismail \& Muyassar H. Abualreesh, Pp. 19553-19565

Disentangling earthworm taxonomic stumbling blocks using molecular markers

- Azhar Rashid Lone, Samrendra Singh Thakur, Nalini Tiwari, Olusola B. Sokefun \&

Shweta Yadav, Pp. 19566-19579

A reference of identification keys to plant-parasitic nematodes (Nematoda: Tylenchida) Tylenchomorpha)

- Reza Ghaderi, Manouchehr Hosseinvand \& Ali Eskandari, Pp. 19580-19602

Short Communications

Catalogue of herpetological specimens from Meghalaya, India at the Salim Ali Centre for Ornithology and Natural History

-S.R. Chandramouli, R.S. Naveen, S. Sureshmarimuthu, S. Babu, P.V. Karunakaran \&

Honnavalli N. Kumara, Pp. 19603-19610
A preliminary assessment of odonate diversity along the river Tirthan, Great Himalayan National Park Conservation Area, India with reference to the impact of climate change - Amar Paul Singh, Kritish De, Virendra Prasad Uniyal \& Sambandam Sathyakumar, Pp. 19611-19615

A checklist of orthopteran fauna (Insecta: Orthoptera) with some new records in the cold arid region of Ladakh, India

- M. Ali, M. Kamil Usmani, Hira Naz, Tajamul Hassan Baba \& Mohsin Ali, Pp. 19616-19625

New distribution records of two Begonias to the flora of Bhutan

- Phub Gyeltshen \& Sherab Jamtsho, Pp. 19626-19631

Rediscovery of Aponogeton lakhonensis A. Camus (Aponogetonaceae): a long-lost aquatic plant of India

- Debolina Dey, Shrirang Ramchandra Yadav \& Nilakshee Devi, Pp. 19632-19635

Glyphochloa acuminata (Hack.) Clayton var. laevis (Poaceae): a new variety from central Western Ghats of Karnataka, India

- H.U. Abhijit \& Y.L. Krishnamurthy, Pp. 19636-19639

A cytomorphological investigation of three species of the genus Sonchus L. (Asterales: Asteraceae) from Punjab, India

- M.C. Sidhu \& Rai Singh, Pp. 19640-19644

Dryopteris lunanensis (Dryopteridaceae) - an addition to the pteridophytic diversity of India

- Chhandam Chanda, Christopher Roy Fraser-Jenkins \& Vineet Kumar Rawat, Pp. 1964519648

Notes

First record of Spotted Linsang Prionodon pardicolor (Mammalia: Carnivora:

Prionodontidae) with photographic evidence in Meghalaya, India

- Papori Khatonier \& Adrian Wansaindor Lyngdoh, Pp. 19649-19651

First record of the Eastern Cat Snake Boiga gocool (Gray, 1835) (Squamata: Colubridae) from Tripura, India

- Sumit Nath, Biswajit Singh, Chiranjib Debnath \& Joydeb Majumder, Pp. 19652-19656

First record of the genus Tibetanja (Lepidoptera: Eupterotidae: Janinae) from India - Alka Vaidya \& H. Sankararaman, Pp. 19657-19659

Austroborus cordillerae (Mollusca: Gastropoda) from central Argentina: a rare, little-known land snail

- Sandra Gordillo, Pp. 19660-19662

Intestinal coccidiosis (Apicomplexa: Eimeriidae) in a Himalayan Griffon Vulture Gyps himalayensis

- Vimalraj Padayatchiar Govindan, Parag Madhukar Dhakate \& Ayush Uniyal, Pp. 1966319664

Two new additions to the orchid flora of Assam, India

- Sanswrang Basumatary, Sanjib Baruah \& Lal Ji Singh, Pp. 19665-19670

Wildlife art and illustration - combining black and white ink drawings with colour: some experiments in Auroville, India

- M. Eric Ramanujam \& Joss Brooks, Pp. 19671-19674
Publisher \& Host

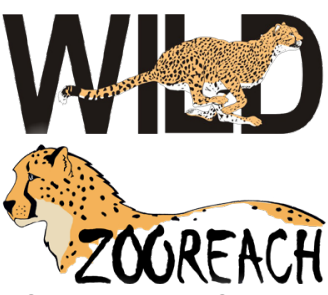

